\title{
Implicações da identificação de subfácies e alterações deutéricas para a gênese e a evolução do albita granito rico em $F$ no depósito de Sn-Nb-Ta-ETR Madeira (Mina Pitinga, Amazonas, Brasil) Implications of the subfacies and deuteritic alterations identification in the F-rich albite granite at the Madeira Sn-Nb-Ta-ETR deposit (Pitinga Mine, Amazonas, Brazil)
}

\author{
Juliano Nunes Rodrigues ${ }^{1}$ (D), Luiz Henrique Ronchi ${ }^{2}$ (D), Artur Cezar Bastos Neto ${ }^{1,3}$ (D), Vitor Paulo Pereira ${ }^{4}$ \\ 'Universidade Federal do Rio Grande do Sul - UFRGS, Instituto de Geociências, Programa de Pós-Graduação em Geociências, \\ Avenida Bento Gonçalves, 9.500, CEP: 91501-970, Porto Alegre, RS, BR (juliano.sul@hotmail.com, artur.bastos@ufrgs.br) \\ 2Universidade Federal de Pelotas - UFPel, Centro das Engenharias, RS, BR (Ihronchi@hotmail.com) \\ ${ }^{3}$ Universidade La Salle, Programa de Pós-Graduação em Avaliação de Impactos Ambientais. \\ Canoas, RS, BR (artur.neto@unilasalle.edu.br) \\ ${ }^{4}$ Universidade Federal do Rio Grande do Sul - UFRGS, Instituto de Geociências, Porto Alegre, RS, BR (vitor.pereira@ufrgs.br)
}

Recebido em 30 de janeiro de 2018; aceito em 31 de agosto de 2018.

\begin{abstract}
Resumo
O albita granito de Pitinga, localizado no estado do Amazonas, em geral porfirítico e de composição modal monzogranítica a granodiorítica, possui uma complexa variação mineralógica e petrográfica, resultante tanto de processos da transição magmático-hidrotermal como de alterações deutéricas. O mapeamento da frente de lavra norte no contato das subfácies de borda (albita granito de borda) e de núcleo (albita granito de núcleo), a petrografia e a geoquímica de amostras representativas revelam duas paragêneses parcialmente superpostas de alteração no albita granito de borda, uma marrom avermelhada com relictos de mica verde rica em ferro e outra vermelha, onde a mica verde foi substituída por clorita e fluorita e/ou argila amarela. Adicionalmente, o albita granito de núcleo cinza porfirítico é transformado gradualmente em porfirítico branco, mais rico em albita; amarelo, quando argilizado por ilita e caulinita; com manchas localizadas de óxidos de ferro vermelhas, silicificado e criolitizado. Tanto o quartzo tardio (silicificação) como a criolita possuem inclusões fluidas aquosas primárias com temperaturas de homogeneização entre 100 e $250^{\circ} \mathrm{C}$ e salinidade até $26 \%$ peso eq. $\mathrm{NaCl}$. Ambas as subfácies, albita granito de borda e de núcleo, são cortadas por corpos irregulares brancos afaníticos compostos essencialmente por quartzo e albita. O padrão de elementos terras raras dos corpos afaníticos brancos é similar ao padrão do albita granito de borda e do albita granito de núcleo, porém com a soma total de elementos terras raras menor, sugerindo cogeneticidade. A subfácies albita granito de borda resulta do resfriamento concêntrico da câmara magmática inicial produzindo uma borda que sofreu alteração autometassomática por fluidos deutéricos, criando os óxidos de ferro que lhe conferem a cor marrom-avermelhada. Com a continuação do resfriamento do magma, cristaliza-se o albita granito de núcleo cinza e corpos maciços de criolita hidrotermal. Adicionalmente, possíveis processos, como queda de pressão ou resfriamento rápido, poderiam ser responsáveis pela textura porfirítica com matriz afanítica; pela ebulição (first boiling) exsolvendo fases deutéricas; pela esponja de minerais (crystal mush) criando texturas com criolita e quartzo tardio intersticiais (silicificação) no albita granito de borda e no albita granito de núcleo e pressão filtrante (filter pressing) promovendo a circulação de fluidos e voláteis que criaram a cor vermelha de alteração do albita granito de borda, e alteração deutérica local vermelha e amarela no albita granito de núcleo. Finalmente, uma fase de albitização afanítica branca corta tanto o albita granito de borda quanto o albita granito de núcleo.
\end{abstract}

Palavras-chave: Albita granito; Deutérica; Hidrotermal; Pitinga; Depósito Madeira; Amazonas.

\begin{abstract}
The Pitinga albite granite, located in the State of Amazon, northern Brazil, compositionally ranging from monzogranite to granodiorite, has a complex mineralogical and petrographic diversity due both to magmatic-hydrothermal transition and deuteric alteration processes. Mapping of the north mining front at the contact between the border subfacies (border albite granite) and core subfacies (core albite granite), petrographic description and geochemical analysis of representative samples showed two partially superposed border albite granite alteration paragenesis: the first one is red-brown, characterized by
\end{abstract}


traces of green Fe-rich mica, and the other is red, where this green Fe-rich mica was replaced either by fluorite and chlorite and/or yellow clay. The porphyritic gray core albite granite is gradually transformed in to a white porphyritic rock richer in albite; to a yellow when argillizedillite and kaolinite rock; locally with red iron oxide spots, silicification and criolitization. As the late quartz (silicification) cryolite shows, primary aqueous fluid inclusions with homogenization temperatures from 100 to $250^{\circ} \mathrm{C}$ and salinity up to $26 \mathrm{wt}$. $\% \mathrm{NaCl}$ eq. Both border albite granite and core albite granite subfacies are cut by irregular aphanitic white rock bodies essentially composed by quartz and white albite. The rare earth elements pattern of these white aphanitic rocks is similar to border albite granite and core albite granite, but with lower total contents, suggesting that they are coeval. The border albite granite subfacies was the first formed during a concentric magmatic chamber cooling process and suffered autometasomatic deuteric alteration creating the red-brown iron oxides. Continuous magma chamber cooling could have created the gray CAG and hydrothermal cryolite massive lens. Additionally, possible processes like pressure loss or quenching could be responsible for the porphyritic texture with aphanitic matrix; first boiling exsolving deuteric phases; crystal mush creatingthe cryolite and quartz interstitial (silicification) textures and filter pressing promoting deuteric fluids and volatiles circulation responsible for the red border albite granite alteration; for border albite granite and core albite granite late quartz and, in the core albite granite, local yellow and red deuteric alteration. Finally, an albitization white aphanitic phase (white albite granite) cut both border albite granite and core albite granite.

Keywords: Albite granite; Deuteric; Hydrothermal; Pitinga; Madeira deposit; Amazonas.

\section{INTRODUÇÃO}

Durante a cristalização da cúpula de plútons granitoides ocorre uma cristalização concêntrica, de fora para dentro (Hildreth e Wilson, 2007). É consenso que câmaras magmáticas evoluem lentamente em direção a composições mais ricas em sílica, em temperaturas mais baixas. Porém, essa evolução pode ser afetada por processos complexos como, entre outros, a formação de crystal mush, uma espécie de esponja de cristais, da qual, por meio de processos de compactação, pode ser extraído um líquido silicático que pode corroer os minerais já cristalizados, inclusive os fenocristais. Por outro lado, nem sempre os grandes cristais de rocha porfirítica se formaram antes da matriz. Assim como a adição de água rebaixa o ponto de fusão de magmas, a perda de fase fluida aquosa nas encaixantes rapidamente aumenta a temperatura de cristalização (liquidus), o que resulta na rápida cristalização de parte do líquido remanescente com os minerais previamente formados e pode produzir textura porfirítica (Winter, 2001; Gill, 2014).

Burnham (1997) enfatiza que, durante a queda de P e $\mathrm{T}$ da câmara magmática, ocorre gradualmente uma separação de fluidos, nas formas de salmouras imiscíveis e de fases ricas em vapor representadas por inclusões fluidas com temperaturas de homogeneização e salinidades variáveis, eventualmente saturadas. Assim, a composição de fluidos hidrotermais magmáticos parece variar com o conteúdo em metais, como o $\mathrm{Cu}$, o Sn e o $\mathrm{W}$, além da $\mathrm{P}$ e T. Por exemplo, em magmas cristalizados em baixas pressões ( $<1,3$ kbar), a salinidade do fluido magmático aumenta com o grau de cristalização, enquanto que, em altas pressões, ocorre o contrário.

Hekinian (1982, p. 329) refere-se à alteração deutérica "como alteração magmática de baixa temperatura relacionada à solidificação de um líquido silicático. $\mathrm{O}$ termo deutérico é restrito a reações envolvendo mudanças nas fases minerais primárias durante o processo de cristalização magmática. $\mathrm{O}$ agente da alteração deutérica é o material volátil dissolvido no magma". Bates e Jackson (1987) enfatizam o caráter aquoso das soluções deutéricas separadas do mesmo corpo de magma. Hekinian (1982, p. 329) detalha ainda que:

O termo autometassomatismo pode ser usado no lugar de deutérico quando a rocha cristalizada é alterada por sua própria fração líquida tardia. É difícil distinguir entre minerais formados durante reações magmáticas tardias daqueles depositados por soluções fluidas penetrando minerais pré-existentes. Os minerais ou compostos amorfos formados no final da cristalização estão localizados nos interstícios dos minerais da matriz, em vesículas ou alinhados nas paredes de veios e/ou cavidades. O material neoformado é considerado como parte do líquido silicático original que deu origem aos constituintes da rocha total. A composição e quantidade de material deutérico dependem do grau de resfriamento, da disponibilidade de líquido residual e da sua composição. O melhor critério para se reconhecer minerais deutericamente alterados é a identificação do pseudomorfismo dos minerais primários.

Ao longo de um processo complexo de resfriamento e queda de pressão, fluidos e voláteis diversos podem ser exsolvidos na fase de transição magmático-hidrotermal, produzindo alterações hidrotermais e/ou metassomáticas na porção de rocha já consolidada. Todos esses processos podem ser complicados pela circulação de fluidos provenientes das rochas encaixantes e de origens diversas, por exemplo, meteórica ou metamórfica (Cathelinau et al., 1988; Cobbing, 2000).

O presente artigo enfoca as alterações deutéricas registradas numa rocha de composição e evolução muito 
incomuns. Trata-se do albita granito (AG) que hospeda o minério de Sn-Nb-Ta (F, ETR, Zr, Hf, U e Th) do depósito Madeira, na mina Pitinga. Nesse depósito de classe mundial (Costi, 2000; Costi et al., 2009), o minério disseminado (164 Mt) ocorre nas duas subfácies - AG de núcleo (AGN) e AG de borda (AGB). Adicionalmente, também ocorre, na parte central do AGN, um depósito hidrotermal de criolita maciça (Bastos Neto et al., 2009) com $10 \mathrm{Mt}$. Este trabalho foi focalizado na frente de lavra norte, onde, além de uma grande exposição representativa das duas subfácies, também ocorrem outras variações do AG relacionadas a processos deutéricos.

O objetivo deste trabalho foi, por meio do estudo petrográfico, geoquímico e de inclusões fluidas dos tipos litológicos presentes, contextualizar as alterações deutéricas descritas na evolução do AG Madeira, principalmente no que tange à distinção de subfácies e à evolução da tão diversificada e singular paragênese mineral e de alteração dessa rocha/minério.

\section{MATERIAIS E MÉTODOS}

Com o objetivo de reconhecer e comparar os diversos tipos litológicos, foi realizada a descrição detalhada da frente de lavra na borda norte do AG Madeira, onde ocorre uma boa exposição do contato entre o AGN e o AGB. Baseado nas diferenças de cor, mineralogia e textura, foram coletadas 38 amostras e confeccionadas 26 lâminas delgadas no laboratório de laminação da Universidade do Vale do Rio dos Sinos (UNISINOS), São Leopoldo, Rio Grande do Sul. Com a petrografia, buscou-se identificar os diversos tipos litológicos, a alteração hidrotermal, detalhar as relações paragenéticas, a sucessão mineral, e realizar a classificação modal dos litotipos. Ainda com base na petrografia, foram selecionadas 17 amostras representativas das principais variações litológicas e alterações para análises geoquímicas em rocha total realizadas pela Analytical Laboratories LTD. (ACME), Canadá. Análises de microscopia eletrônica de varredura (MEV) acoplada a EDS (Energy Dispersive X-Ray Spectrometer) e difratometria de raios $\mathrm{X}$ foram realizadas no Centro de Microscopia Eletrônica (CME) da Universidade Federal do Rio Grande do Sul (UFRGS), buscando, especialmente, caracterizar os minerais não prontamente identificados pela microscopia óptica. O modelo de MEV utilizado, EVO 50 da marca Zeiss, possui filamento de tungstênio que opera em tensões de 0,2 a $30 \mathrm{kV}$, e sua resolução nominal é de $3 \mathrm{~nm}$ operando em $30 \mathrm{kV}$. Foi utilizado difratômetro de raios X Siemens D-5000, no intervalo entre 2 e $82^{\circ} 2 \mathrm{e}$ - com passo de $0,02^{\circ}$ no tempo de $2 \mathrm{~s}$, utilizando radiação $\mathrm{Cu}$-Kalfa e filtro de níquel. Para as argilas, foram realizadas análises de amostras natural, glicolada e calcinada a $500^{\circ} \mathrm{C}$. Duas lâminas bipolidas de quartzo tardio com aspecto de fenocristais e relacionados a processos de alteração hidrotermal (silicificação) tiveram suas inclusões fluidas petrograficamente descritas e analisadas por microtermometria utilizando a platina Linkam THMSG600 acoplada a um microscópio óptico biológico (NIKON 50i), equipado com uma objetiva de 50x, no Laboratório de Mineralogia e Petrologia da Universidade Federal de Pelotas (UFPel). A calibração do aparelho foi realizada com inclusão fluida aquocarbônica sintética $\left(-56,6^{\circ} \mathrm{C}\right.$ synth.fi's), água desmineralizada $\left(0,0^{\circ} \mathrm{C}\right)$ e produtos de ponto de fusão conhecido como nitrato de sódio $\left(308^{\circ} \mathrm{C}\right)$ e dicromato de potássio $\left(398^{\circ} \mathrm{C}\right)$. A precisão das medidas é de $\pm 0,1^{\circ} \mathrm{C}$ e a salinidade das inclusões fluidas foi determinada de acordo com Bodnar (2003).

\section{ENQUADRAMENTO GEOLÓGICO}

\section{Geologia regional}

O depósito Madeira, inserido em um AG (Figura 1), localiza-se no sul do Escudo das Guianas. Na região de Pitinga, destaca-se a Suíte Madeira, que é composta por três plútons graníticos denominados de Europa, Água Boa e Madeira, propriamente dito. Esses granitos são intrusivos em rochas vulcânicas ácidas do Grupo Iricoumé paleoproterozoico (Lenharo et al., 2003). Os granitos Água Boa e Madeira são mineralizados em Sn. Segundo Costi et al. (2000), os granitos foram agrupados por apresentarem idades similares em torno de $1822 \mathrm{Ma}$ $(\mathrm{Pb}-\mathrm{Pb})$ e pertencerem ao mesmo evento magmático. O granito Europa foi pouco estudado, pois se encontra quase inteiramente em área protegida (reserva indígena). Porém, Costi et al. (2000) o identificaram e classificaram como um granito hipersolvus de caráter peralcalino composto por feldspato, biotita, quartzo e riebeckita. O granito Água Boa possui forma elíptica, com orientação do eixo maior NE-SW, e abrange a área de 350 $\mathrm{km}^{2}$. Segundo Lenharo et al. (2003), ele é composto de quatro fácies, sendo a mais precoce um anfibólio-biotita-sienogranito, seguido por um biotita sienogranito de textura porfirítica, um biotita-granito e a mais jovem, um topázio-granito porfirítico. Geoquimicamente, essas fácies possuem natureza alcalina e são classificadas como granitos do tipo-A, de caráter metaluminoso a peraluminoso (Horbe et al., 1991).

\section{Granito Madeira}

O granito Madeira é um stock alongado com direção geral NE-SW, área aproximada de $60 \mathrm{~km}^{2}$ e quatro fácies: anfibólio-biotita sienogranito, biotita-feldspato alcalino granito, 
feldspato alcalino granito hipersolvus e AG (Figura 1B). A fácies anfibólio-biotita sienogranito, a mais antiga, ocorre ao longo do contato das bordas nordeste, noroeste $\mathrm{e}$ sudoeste do stock; tem sido denominada de "granito rapakivi" e possui coloração avermelhada com manchas pretas e verdes (Costi, 2000). Petrograficamente, é uma rocha de textura equigranular a porfirítica, composta por feldspato potássico $(\sim 70 \%)$, quartzo $(\sim 20 \%)$ e plagioclásio $(\sim 10 \%)$, e possui como minerais acessórios clinopiroxênio, zircão, fluorita, titanita e apatita. Algumas de suas texturas indicam níveis crustais rasos e seu caráter é predominantemente metaluminoso (Costi, 2000).

Relações de campo demonstram que o biotita-feldspato alcalino granito é intrusivo no anfibólio-biotita sienogranito. Os contatos com a fácies AG são reativos. Sua coloração é avermelhada com pontuações escuras disseminadas. Possui textura predominantemente equigranular e localmente porfirítica, composta de feldspato potássico $(\sim 55 \%)$, quartzo $(\sim 30 \%)$, plagioclásio $(\sim 10 \%)$ e biotita $(\sim 5 \%)$, contendo ainda acessórios como fluorita, zircão, topázio e anatásio. Geoquimicamente, é classificado como metaluminoso a peraluminoso e sua idade é de $1822 \pm 2 \mathrm{Ma}\left({ }^{207} \mathrm{~Pb} /{ }^{206} \mathrm{~Pb}\right.$ em zircão, Costi, 2000).

O feldspato alcalino granito hipersolvus possui textura porfirítica, com matriz de granulação fina a média, coloração róseo-avermelhada e cinza-claro a cinza-rosado, constituída essencialmente por feldspato potássico e quartzo. Os contatos com o AG são transicionais e os processos metassomáticos de albitização e epi-sienitização são frequentes. Foi estabelecida a idade de $1818 \pm 2$ Ma por meio do método ${ }^{207} \mathrm{~Pb} /{ }^{206} \mathrm{~Pb}$ em zircões (Costi, 2000).

$\mathrm{O} A \mathrm{~A}$ é a fácies mais tardia e ocupa a parte central do granito Madeira, apresentando forma alongada com orientação N-S do eixo maior e extensão de $1,8 \mathrm{~km}$ e $1,5 \mathrm{~km}$ no eixo menor. Esta fácies é intrusiva em todas as demais do granito Madeira, pode apresentar texturas pegmatíticas. Horbe et al. (1991) apontaram diferenças petrográficas, geoquímicas e metalogenéticas no AG que permitiram dividi-lo em subfácies de núcleo (AGN) e de borda (AGB).

A sucessão mineralógica e paragenética nas subfácies AGB e AGN foi delineada em diversos trabalhos anteriores (Costi, 2000; Bastos Neto et al., 2005; Weber et al., 2007; Costi et al., 2009; Ronchi et al., 2011), estabelecendo fases ortomagmáticas precoces (paragênese dos fenocristais, AGN cinza (AGNc)) e tardias (paragênese da matriz albítica), fases relacionadas à transição magmático-hidrotermal (textura pegmatítica) e, pelo menos, duas fases hidrotermais principais, uma responsável pelo autometassomatismo da borda, formando o AGB, e outra responsável pela formação da criolita maciça, argilização, fases diversas de silicificação, oxidação dos minerais ricos em ferro, albitização (AG branco afanítico) e alteração da mica verde do AGN (Costi, 2000; Bastos Neto et al., 2005; Ronchi et al., 2011).

Esse tipo de processo, denominado autometamórfico, que corresponde ao autometassomatismo ou a alterações
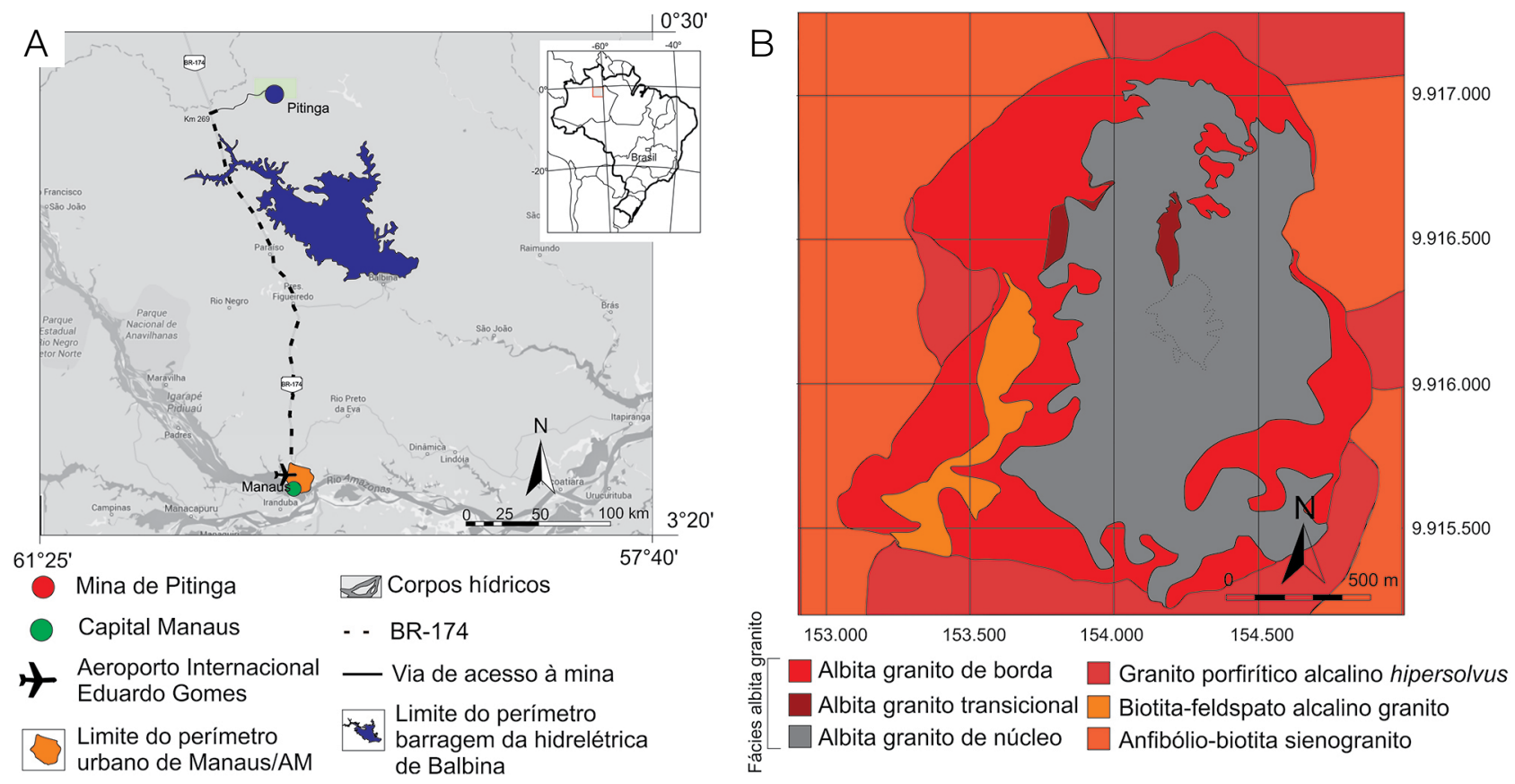

Figura 1. (A) Mapa de localização da Mina de Pitinga; (B) mapa geológico do albita granito e encaixantes imediatas (Minuzzi, 2005). 
deutéricas descritos por Winter (2001), faz parte do resfriamento ígneo normal e ocorre em temperaturas relativamente moderadas em um ambiente no qual $\mathrm{H}_{2} \mathrm{O}$ é liberada (exsolvida) de um líquido silicático residual ou externamente introduzida. $\mathrm{O}$ mapeamento e a petrografia de detalhe da frente de lavra da borda norte, no contato do AGB e do AGN (Figuras 2 e 3), refletiram essa bem estabelecida sucessão mineral e acrescentaram algumas novas fases de alteração hidrotermal abaixo discutidas, em especial o AG branco, intrusivo no AGB e no AGN (Figura 2B, número 15). Destaca-se também a presença no $A G$ de minerais, como a xenotima $\left(\mathrm{YPO}_{4}\right)$ e a fluocerita $\left[(\mathrm{Ce}, \mathrm{La}) \mathrm{F}_{3}\right]$ (Pires 2010) e processos, como a columbitização do pirocloro (Minuzzi et al., 2006).

Costi (2000) caracteriza uma terceira fase, o AG transicional, como uma zona de transição das subfácies AGB e AGN. A mineralogia e a petrografia do AG transicional são definidas pela desestabilização de minerais do grupo do pirocloro, criolita e micas ricas em ferro. Outra característica descrita pelo autor é a pigmentação de uma rocha similar ao AGN por "microgrânulos" opacos vermelhos e escuros. Essa rocha não aparece no contato estudado na borda norte. Conforme Costi et al. (2005), a presença de riebeckita no AGN está associada ao caráter peralcalino desta subfácies, diferentemente do AGB, que possui caráter peraluminoso a metaluminoso, o que não é compatível com a existência de riebeckita. Costi et al. (2009) reconhecem a importância de processos hidrotermais no AG, mas concluem que "as feições essenciais do AG Madeira são de origem magmática".

\section{RESULTADOS}

\section{Relações de campo}

A Figura 2A mostra as variações litológicas na borda norte do $A G$, em que 1 é o biotita-feldspato alcalino granito encaixante, 2 é o AGB marrom-avermelhado, 3 é o AGB vermelho e em 4 predomina o AGNc e o AGN branco (AGNb) porfiríticos. Localmente em 4, ocorrem ainda o AGN amarelo (AGNa) e o AGN vermelho (AGNv). As amostras muito silicificadas do AGB foram denominadas AGBs. Existem porções brancas discordantes tanto no AGB quanto no AGN, denominadas AG branco (afanítico, Figura 3).

O AGN possui textura porfirítica a localmente seriada. Macroscopicamente, apresenta cor predominantemente cinza e branca com proporções modais muito variáveis e que, conforme Costi et al. (2005), muitas vezes são similares e em torno de 20 a $30 \%$, tanto de quartzo como de feldspato alcalino e albita (Weber et al., 2007). Porém, esse AGN, seja na porção central da cava a céu aberto ou próximo ao contato com o $\mathrm{AGB}$, mostra uma variação de cores característica, refletindo composições mineralógicas diversas. O AGNc (1 na Figura 2C) pode se tornar branco (2 na Figura 2C) ou localmente amarelo e/ou friável no entorno de falhas e fraturas ( 3 na Figura $2 \mathrm{C}$ ) e vermelho (4 na Figura 2C). Por sua vez, o AGB, hidrotermalmente alterado, também possui textura porfirítica e proporções modais de quartzo, feldspato alcalino e albita similares ao AGN, sua cor pode ser marrom-avermelhada ou vermelha (Figura 2A), devido a uma fina poeira vermelha de óxidos de ferro, pervasiva em toda a rocha ou concentrada em fraturas irregulares muito finas. Dispersa no AGB ocorrem manchas de uma rocha escura composta por uma associação de fluorita roxa com clorita, visíveis a olho nu. Essa associação é similar ao localmente observado em lâminas delgadas quando da alteração mica verde (tetraferrífera, Costi, 2000) no AGN e no AGB.

As variações mais importantes de cores e mineralogia do AG são mostradas com mais detalhe na Figura 3. Na borda norte, destaca-se a passagem do AGNc para o AGNb, ambos porfiríticos, iniciando com pequenas manchas brancas de albita (Figura 3A), eventualmente associadas a fraturas, e que podem se tornar a feição dominante. Além dessa transição, foram observados corpos irregulares tardios superficialmente amarelos, mas brancos no interior, aqui denominados AG branco, com textura equigranular afanítica, discordantes e recortando todo o afloramento do AGB (e.g., pontos 13 e 15 na Figura 2B). Corpos equivalentes também cortam o AGNc (2 nas Figuras 2C, 3C e 3E). No AGN, a fluorita roxa pode estar associada com essa fase $\mathrm{AG}$ branco (afanítica); e no AGB, a fluorita está associada com a fase avermelhada (Figuras 3B e 3C).

A difratometria de raios $\mathrm{X}$ identificou ilita e caulinita nas porções amareladas no AGNa (3 na Figura 2C), e as manchas vermelhas parecem resultado de oxidação de minerais ricos em ferro (4 na Figura 2C), tanto em falhas e fraturas (3 e 5 na Figura 2C) como no contato com o AG branco (afanítico Figura 3E). Esse fenômeno de oxidação de minerais ricos em ferro no AGB é considerado como resultado de um processo de autometassomatismo (Costi, 2000).

Finalmente, outra feição importante observada em campo corresponde ao AGNc, muito rico em criolita (9\%), que chega a ser visível a olho nu (Figura 3F), localizado em meio ao AGB com contatos não intrusivos e aparentemente gradacionais (7 na Figura $2 \mathrm{C}$ ). Toda essa variação de cores, mineralogia e litologia foram estudadas em lâminas delgadas, e a Figura 2B apresenta a localização das amostras coletadas.

\section{Classificação e composição modal}

Os afloramentos e as amostras de AGNc e AGNb porfiríticos aqui estudados ocorrem como manchas irregulares e em proporções variadas entre os pontos 1 e 6 , na Figura 2B. 
A porção cinza é caracterizada por uma maior presença de minerais acessórios escuros da paragênese dos fenocristais, como mica verde rica em ferro (tetraferrífera), mica rica em lítio (polilitionita), anfibólio azul (riebeckita), cassiterita, xenotima, gagarinita-(Y) e criolita magmática (Figuras 4A e 4B), associados aos fenocristais de quartzo e feldspato (Figuras 4C e 4D).

Alguns minerais, como zircão e pirocloro, estão majoritariamente associados com a paragênese dos fenocristais, mas eventualmente ocorrem associados com a alteração
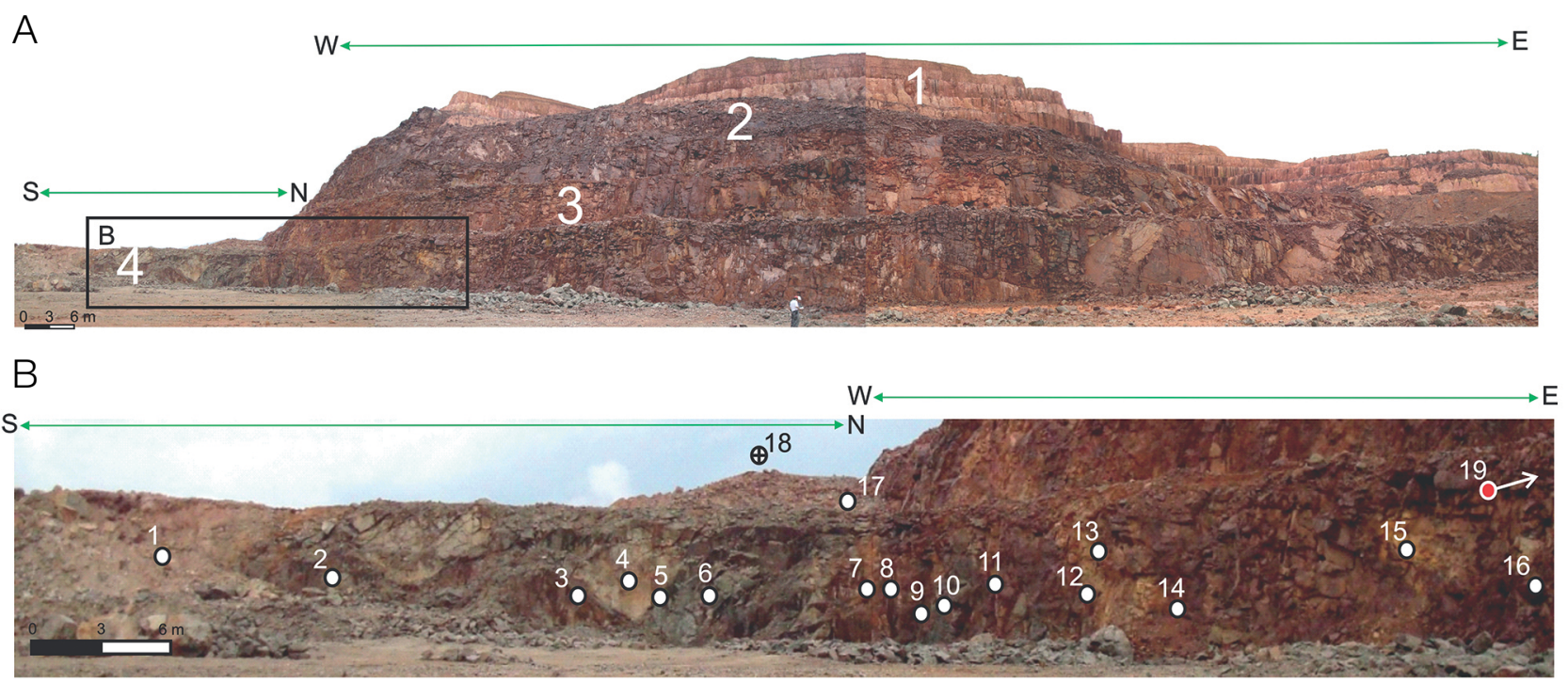

C

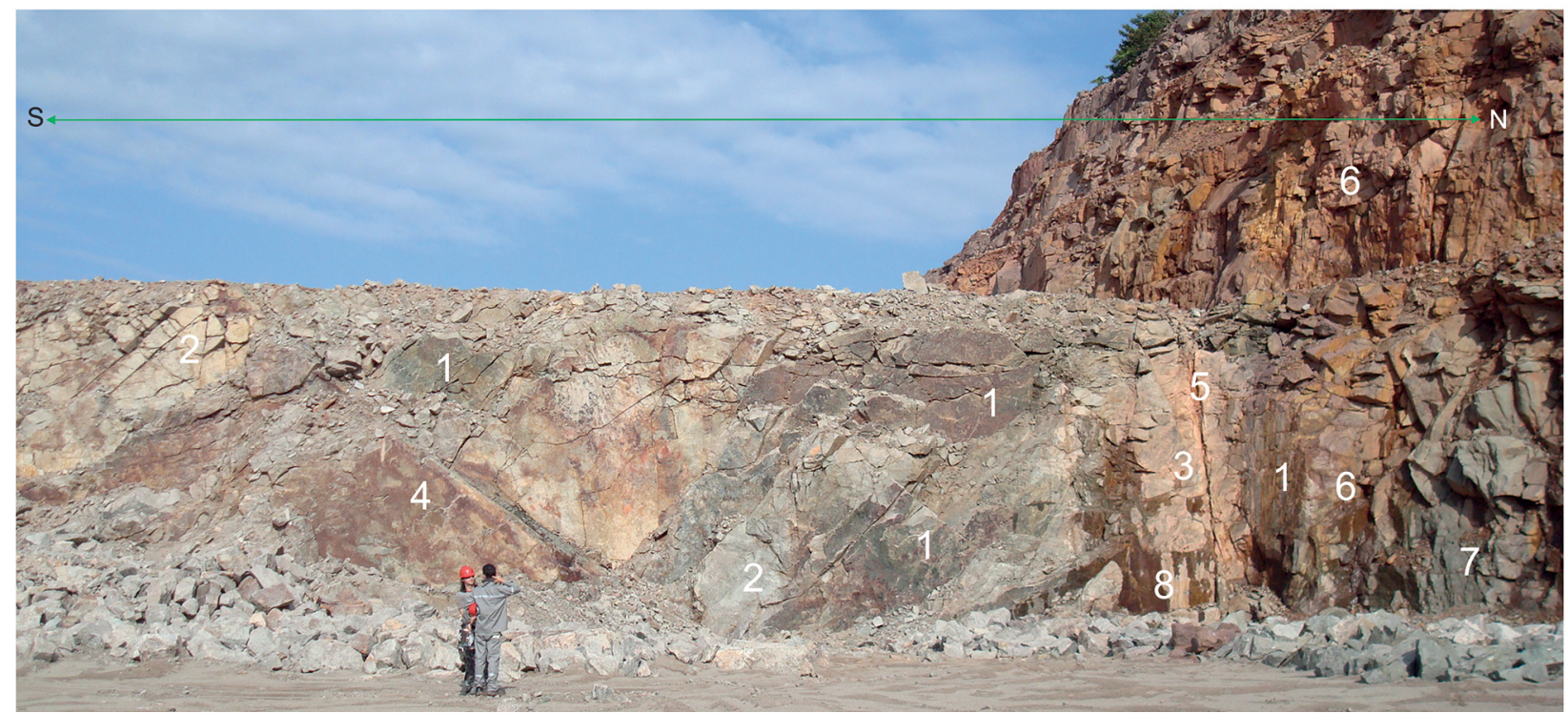

Figura 2. Frente de lavra na borda norte do depósito Madeira: (A) 1 - biotita-feldspato alcalino granito encaixante; 2 albita granito de borda marrom-avermelhado; 3 - albita granito de borda vermelho; 4 - predomínio de albita granito cinza com porções brancas. As manchas brancas menores, tanto no albita granito de borda quanto no albita granito de núcleo, correspondem ao AG branco (afanítico). Em campo, a frente de lavra E-W forma claramente um ângulo reto com a parede N-S; (B) os números de 1 a 19 correspondem a pontos de coleta de amostras. Os pontos 18 e 19 estão fora dessa foto; (C) detalhe do contato do albita granito de núcleo com o albita granito de borda; 1 - albita granito de núcleo cinza; 2 - albita granito de núcleo branco; 3 - albita granito de núcleo amarelo; 4 - albita granito de núcleo vermelho; 5 - falha encobrindo parcialmente o contato; 6 - albita granito de borda escuro com muita fluorita roxa e clorita verde visíveis a olho nu; 7 - albita granito de núcleo rico em criolita; 8 - porção mais escura apenas por estar molhada. 

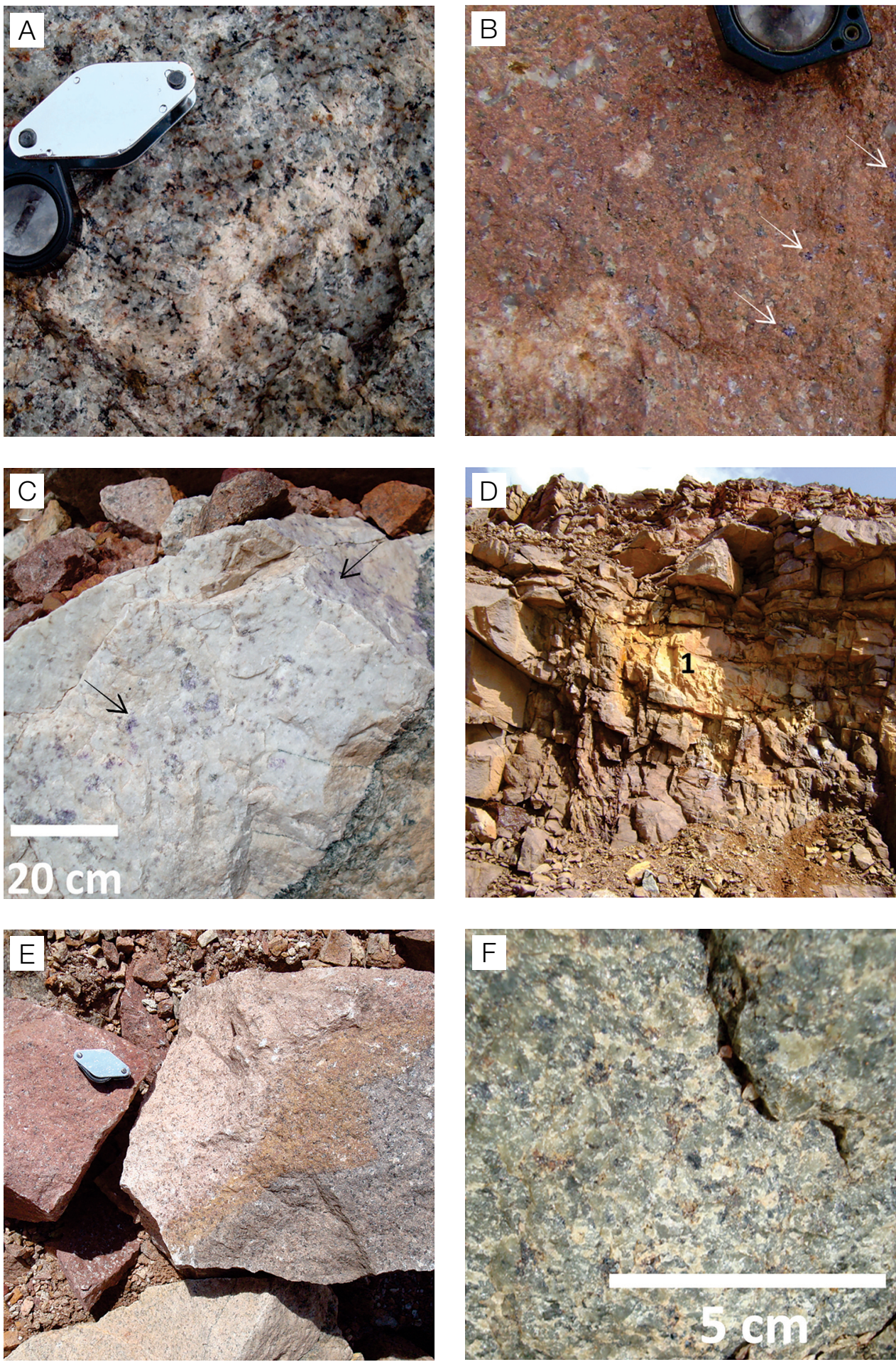

Figura 3. Detalhe das variações litológicas na borda norte do albita granito. (A) Albita granito de núcleo cinza parcialmente substituído por albita granito branco; (B) albita granito de borda vermelho rico em fluorita roxa disseminada e indicada por setas (notar as manchas brancas sugerindo substituição similar ao albita granito de núcleo da Figura A); (C) contato do albita granito de núcleo cinza com o AG branco afanítico rico em fluorita roxa macrocristalina indicada pelas setas; (D) porção superficialmente amarela em 1 corresponde ao AG branco afanítico cortando o albita granito de borda; (E) blocos soltos mostrando à direita o contato do albita granito de núcleo cinza com o albita granito de núcleo branco fanerítico sem fluorita, comparado com o albita granito de borda vermelho (notar a mancha de oxidação dos minerais ricos em ferro no contato); (F) raro afloramento de enclave de albita granito de núcleo rico em criolita dentro do albita granito de borda. 
hidrotermal. Na porção do AGNb, também porfirítica, predomina a matriz albítica, com quartzo e pouco feldspato alcalino e criolita. A alteração hidrotermal do AGN alterou o U-Pb-pirocloro magmático, formando, sucessivamente, U-pirocloro e columbita, com fluocerita associada, assim como ilita, caulinita, silicificação e fluorita.

O contato entre os minerais magmáticos da paragênese dos fenocristais e da matriz em geral possui aspecto corrosivo, e são pequenas porções no entorno do fenocristal, invasivos a matriz que o circunda, porém localmente é possível observar que o contato entre o AGNc e o AGNb é marcado por uma faixa de óxidos de ferro marrom-avermelhada (Figura 3E). Ao microscópio nesta faixa de contato, tanto os minerais da matriz como os fenocristais são cortados por fraturas muito finas e irregulares preenchidas por óxidos de ferro. Eventualmente, o AGNc apresenta-se avermelhado. Nesse caso, fraturas radiais finas, preenchidas por óxidos de ferro no entorno de zircão e torita, oxidação do ferro das micas verdes ou minerais opacos conferem essa cor à rocha. O AGNa possui a paragênese de fenocristais e matriz corroídas por uma argila amarela identificada por difratometria de raios X, como ilita e caulinita. Eventualmente, observa-se fluorita roxa em fraturas e também corroída pelas argilas. Trata-se de um processo de alteração hidrotermal produzindo argilas. Esse processo é mais evidente no AGB.

O AGB, cujas amostras foram coletadas entre os pontos 8 e 19 na Figura 2B, possui cor, em geral, marrom-avermelhada, principalmente em sua porção superior (2 na Figura 2A), por causa da presença de óxidos de ferro em fraturas e disseminados em toda a rocha (Figuras 4E e 4F). Localmente nas porções mais inferiores (3 na Figura 2A), o AGB possui cor vermelha mais clara, também relacionada aos óxidos de ferro. A mica verde, comum no AGN e no AGB marrom-avermelhado, desaparece no AGB vermelho, tendo sido substituída por clorita e fluorita. Nesse contexto, a presença de argila amarela também é significativa. Acessoriamente, o AGB é constituído por cassiterita, hematita, torita, pirocloro, columbita e xenotima em contatos retos com a paragênese dos fenocristais. Tanto no AGB como no AGN, uma fase de quartzo mais límpido e tardio, que pode corroer tanto os fenocristais como a matriz avermelhada, eventualmente se apresenta como se fosse um fenocristal acomodado entre os cristais da matriz e entre os fenocristais propriamente ditos (Figura 4F). Esse quartzo tardio teve suas inclusões fluidas aquosas estudadas e os resultados aparecem no item correspondente abaixo.

Conforme discutido no item "Geoquímica", o AGN possui caráter peralcalino, compatível com a observada presenca de riebeckita, ao passo que o AGB possui caráter peraluminoso a metaluminoso (Costi, 2000), o que exclui a possibilidade de presença de riebeckita (Winter, 2001; Costi et al., 2005).
A análise modal (Streckeisen, 1967) em 26 lâminas delgadas buscou separar os minerais magmáticos, que podem aparecer como fenocristais ou matriz, dos minerais secundários, tais como o quartzo tardio e plagioclásio do AG branco. As variações mineralógicas essenciais nas subfácies AGN e AGB possuem trend evolutivo similar (Figura 5), variando de monzogranito a tonalito, podendo inclusive chegar a granitoide rico em quartzo. Na Figura 5, os pontos foram plotados com base na contagem modal de minerais essenciais aparentemente magmáticos. Porém, se forem incluídos os minerais secundários, como quartzo tardio e albita, apesar de haver um pequeno deslocamento dos pontos, a classificação ainda se mantém dentro dos limites do mesmo campo, com exceção de duas amostras correspondentes ao AG branco (albitização AGM 24 e AGM 27B), em que não ocorrem fenocristais.

Se a classificação for efetuada contando, ou não, os minerais de alteração hidrotermal, seja o quartzo (da silicificação) ou a albita (da albitização), o resultado não muda substancialmente. Por outro lado, notam-se duas tendências, que são o enriquecimento em albita, resultando na classificação de algumas amostras de AG branco (afanítico), como tonalito, e o enriquecimento em quartzo, resultando em granitoide rico em quartzo. Os máficos em geral não ultrapassam $10 \%$ da contagem modal total, típicos de rochas hololeucocráticas, estão ausentes na fase AG branco (afanítica) e são mais abundantes no AGNc do que no AGNb (porfirítico). No AGB, existe uma correlação positiva entre máficos e quartzo, ao passo que no AGN essa correlação se inverte; ao diminuir a proporção de quartzo, aumenta a de máficos (Figuras 5A e 5B).

Embora as proporções de quartzo e feldspato nessas rochas indiquem uma nomenclatura de monzogranito a granodiorito para o AGB e o AGN e de tonalito para o AG branco afanítico, o sistema de classificação de rochas ígneas da IUGS (International Union of Geological Sciences) permite incluir feições mineralógicas no nome da rocha, tal como AG, o que é amplamente feito para rochas, tais como o AG de Pitinga. Adicionalmente, esse tipo de granito hololeucocrático a leucocrático, rico em metais raros e associado a granitos com texturas pegmatíticas, é um caso particular tradicionalmente denominado de AG (Helba et al., 1997). Se a contagem de pontos do AG branco (afanítico) for plotada no diagrama de classificação de rochas vulcânicas, seria um dacito. Como se trata de uma alteração sódica, optou-se pela denominação AG branco.

\section{Paragênese e sucessão mineral}

A paragênese magmática precoce é representada pelos minerais em equilíbrio textural com os fenocristais e a tardia corresponde aos minerais da matriz em contato reativo com a paragênese 

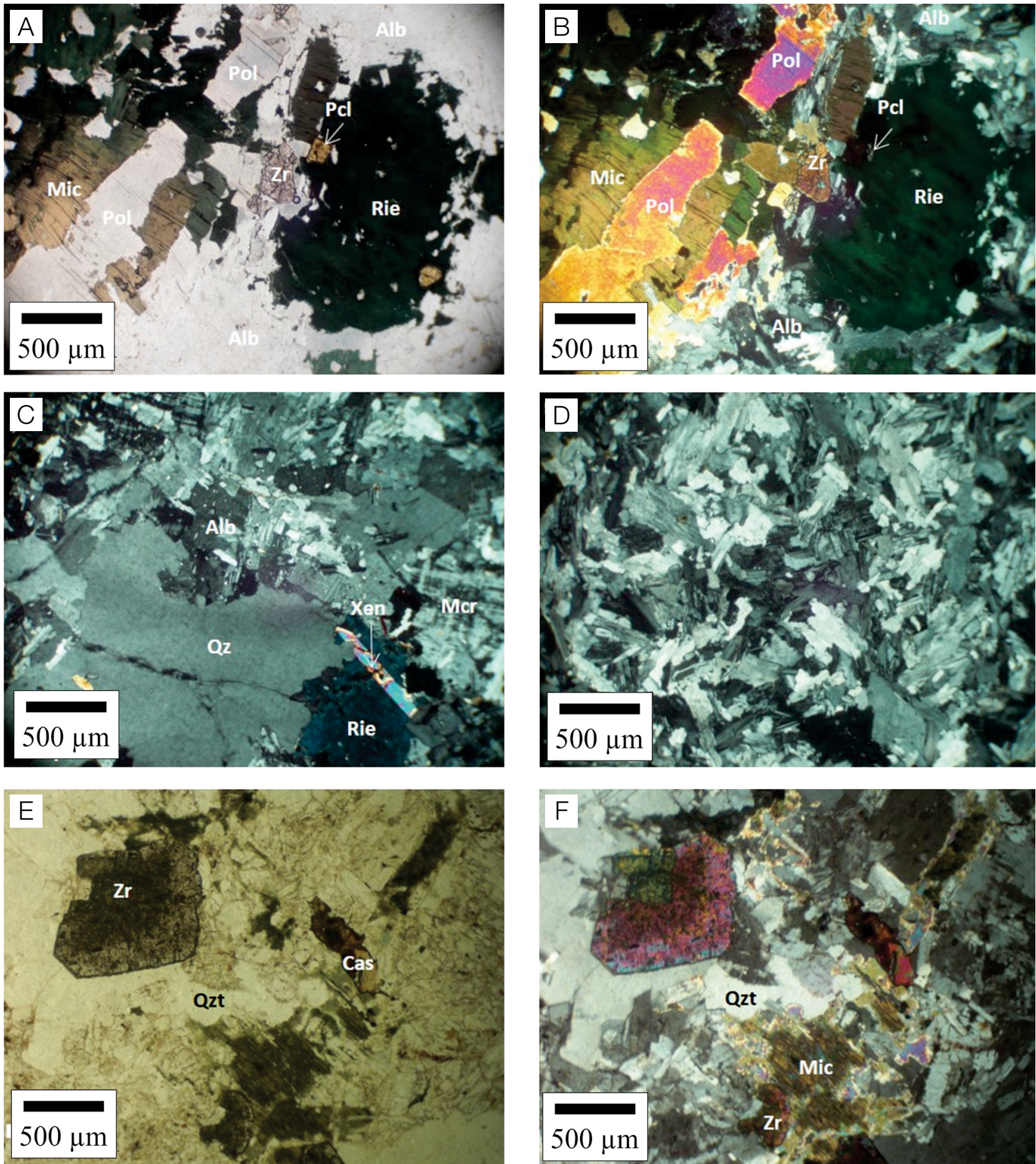

Alb: matriz albítica com quartzo; Pol: polilitionita; Pcl: pirocloro; Zr: zircão; Mic: mica com pleocroísmo verde a marrom; Rie: riebeckita; Qz: quartzo; Xen: xenotima; Mcr: microclínio; Cas: cassiterita; Qzt: quartzo tardio.

Figura 4. Minerais e texturas do albita granito de núcleo cinza e branco e albita granito de borda vermelho. (A) Paragênese dos fenocristais em luz polarizada não analisada; (B) paragênese dos fenocristais em luz polarizada analisada (note os contatos corrosivos da matriz com os fenocristais); (C) fenocristal de quartzo corroído pela matriz albítica com microclínio e quartzo em luz polarizada analisada (note a xenotima associada aos fenocristais); (D) albitização branca com quartzo e albita que corta o albita granito de borda (amostra AGM 24); (E) albita granito de borda marrom-avermelhado (note a poeira fina de óxidos de ferro que conferem a cor vermelha à rocha em luz polarizada não analisada); (F) albita granito de borda marrom-avermelhado (note o quartzo límpido tardio e o zircão zonado em luz polarizada analisada (lâmina 26B)). 
precoce. As paragêneses hidrotermais correspondem aos processos de criolitização, silicificação, oxidação do ferro, cloritização, fluoritização, argilização e albitização (Tabela 1).

Os cristais de quartzo do AGB e do AGN ocorrem como fenocristais com tamanhos de 0,5 a $2 \mathrm{~mm}$ e na matriz possuem tamanho médio de $50 \mu \mathrm{m}$. Ambos variam de anédricos a subédricos. No AGN, a textura snowball é comum e muitas vezes ocorrem microfraturas restritas ao quartzo e que não cortam ou cortam apenas parcialmente os minerais vizinhos. Essas evidências indicam mais de
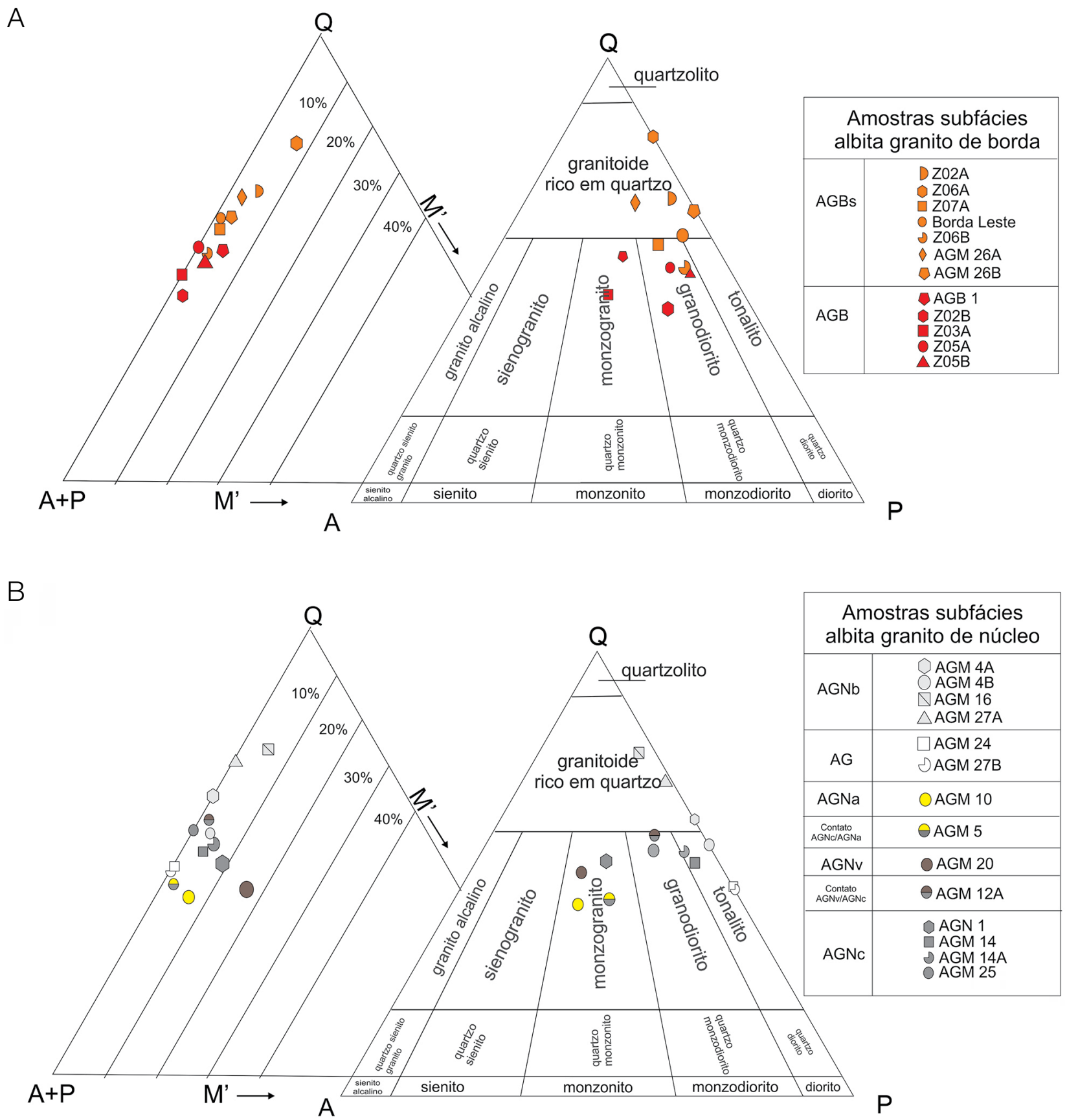

Q: quartzo; A: feldspatos alcalinos; P: plagioclásios; M: máficos; AGBs: subfácies albita granito de borda silicificado; AGB: subfácies albita granito de borda; AGNb: subfácies albita granito de núcleo branco; AG: subfácies albita granito branco; AGNa: subfácies albita granito de núcleo amarelo; AGNv: subfácies albita granito de núcleo vermelho; AGNc: subfácies albita granito de núcleo cinza.

Figura 5. Diagramas QAP e QAPM de minerais essenciais das subfácies albita granito de borda e albita granito de núcleo: (A) albita granito de borda; (B) albita granito de núcleo (Streckeisen, 1967). 
um evento de cristalização no AGN. Tanto no AGB como no AGN, a proporção de quartzo como fenocristal, na rocha como um todo, varia de 20 a $40 \%$, enquanto que o quartzo da matriz do AGN ocupa de 10 a $20 \%$ e, no caso do AGB, de 15 a $35 \%$. A soma dos dois, no AGN e no AGB, atinge de 40 a $60 \%$. No AG branco, os teores de quartzo estão em torno de $45 \%$.

A albita é, em geral, euédrica a subédrica e raramente possui maclas polissintéticas bem definidas. Principalmente no AGB, mas também no AGN, ela é comumente associada à substituição parcial de microclínio, criando a macla de tabuleiro de xadrez (chess-board albite). Análises ao MEV indicaram a ausência de $\mathrm{Ca}$. Os cristais de albita possuem contatos retilíneos entre si e com os cristais de quartzo da matriz, ao passo que, com os fenocristais de quartzo, seu contato é corrosivo. No AGN, ocorre como fenocristal com tamanhos em torno de $1 \mathrm{~mm}$ e em proporções de até $10 \%$. No AGB, o tamanho varia de 50 a $100 \mu \mathrm{m}$ e é raro encontrar fenocristais de albita. Na matriz do AGN e do AGB, as porcentagens de albita variam de 20 a $35 \%$. Em ambas as subfácies, na soma total de fenocristais e matriz, a albita ocupa também de 20 a $35 \%$ do volume da rocha. Nas amostras AG branco, equigranular fino, os teores de albita estão por volta de $50 \%$, e os seus tamanhos variam de 100 a $200 \mu \mathrm{m}$.
O feldspato alcalino pode ser microclínio ou ortoclásio, euédrico a subédrico, com tamanho, em média, de 100 a $500 \mu \mathrm{m}$. Os fenocristais de feldspato alcalino podem ser ausentes ou ocupar até $10 \%$ do volume do AGN e do AGB, ao passo que na matriz também podem ser ausentes ou variar de 10 a $20 \%$ no AGN e até $15 \%$ no AGB. No AG branco, os feldspatos potássicos não ocorrem.

A mica tetraferrífera, preta em amostra de mão do AGN, é verde ao microscópio com variação de pleocroísmo de forte a moderado, em tons de verde-escuro a marrom-esverdeado, e apresenta cristais tabulares a subédricos. Possui tamanhos de 50 até $500 \mu \mathrm{m}$ e pode ter suas clivagens deformadas. Com frequência, ela apresenta sinais de alteração para clorita ou óxidos de ferro que preenchem suas clivagens. Quando em contato com a matriz albítica, ela mostra-se corroída e com bordas denteadas. É comum estar associada com a polilitionita, com a qual possui contatos retilíneos. A polilitionita possui tamanho e clivagem similares aos da mica verde, porém apresenta pleocroísmo de azul-claro a branco e cores de interferência altas. Normalmente, não apresenta os mesmos sinais de alteração descritos na mica verde. No AGB marrom, existem poucos cristais de mica verde, os quais têm tamanhos em torno de $700 \mu \mathrm{m}$, e são muito alterados; nesta rocha, é mais comum a ocorrência de polilitionita com tamanhos de 500 a $700 \mu \mathrm{m}$. No AGB

Tabela 1. Paragênese e sucessão mineral (A: subfácies albita granito de núcleo; B: subfácies albita granito de borda) (modificada de Bastos Neto et al., 2009; Weber et al., 2007; Ronchi et al., 2011).

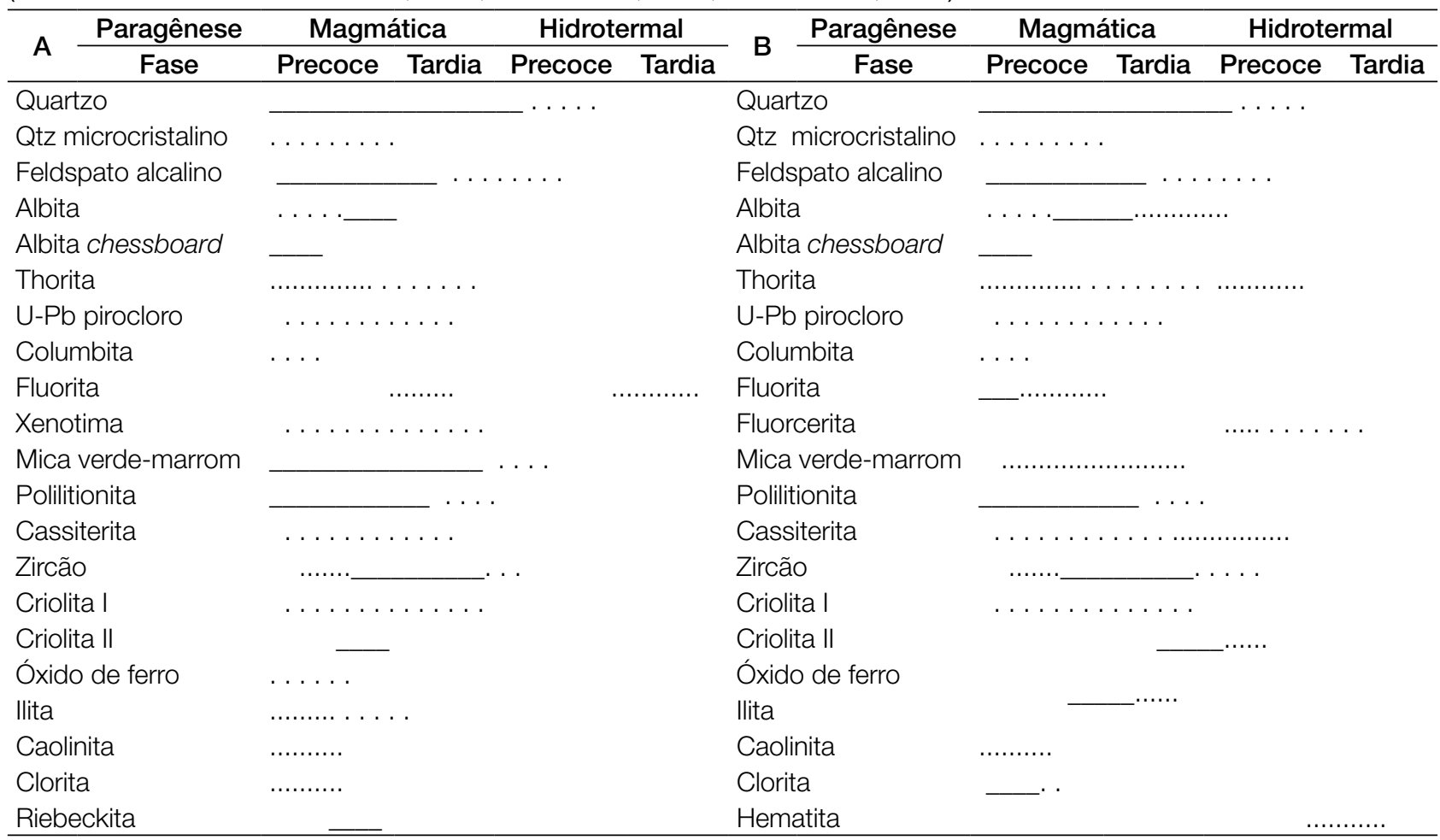


vermelho, a mica verde desaparece, restando a clorita, associada com a fluorita e/ou argila amarela.

A riebeckita é comum no AGN e não é encontrada no AGB. Possui cor azul-escuro, com pleocroísmo de azul a marrom, ocorre como cristais prismáticos, em certos casos fibrosos e até anédricos, podem alcançar tamanho de $2,5 \mathrm{~mm}$. Pode estar associada a criolita e polilitionita, formando agregados que preenchem cavidades possivelmente miarolíticas, as quais indicam uma fase de cristalização magmática tardia.

A cassiterita ocorre disseminada em ambas as subfácies e pode estar associada aos fenocristais ou à matriz, mas, em geral, é encontrada com a criolita, o zircão, a riebeckita e a polilitionita. Na subfácies AGB, é comum a presença de cassiterita associada a óxidos que preenchem interstícios da matriz.

A torita, identificada por sua composição ao MEV, foi observada em quantidades menores que $1 \%$, principalmente na matriz albítica do AGN, com tamanhos menores do que $0,5 \mathrm{~mm}$, por vezes hidrotermalmente alterada, conforme sugere um envelope de óxidos de ferro também presentes em fraturas radiais (Figura 6F).

A fluorita, pouco evidente no AGN, ocorre em tons variando de roxo a incolor, muitas vezes incolor com pontuações roxas, ao passo que, no AGB, é comum sua presença em agregados de cristais ou em cristais anédricos intersticiais incolores ou em tons de cor roxa. Os cristais observados com hábito anédrico estão associados ao preenchimento dos interstícios da matriz ou fraturas, porém também é comum a ocorrência de cristais que apresentam contatos intensamente corrosivos com a paragênese dos fenocristais e com os minerais da matriz. A fluorita parece substituir a mica verde rica em ferro ao longo dos planos de clivagem e progredindo até a completa desestabilização do cristal primário que, no estágio final, é transformado em um agregado composto por fluorita, clorita e opacos. Ao MEV, essa clorita apresentou $\mathrm{Zn}$ em sua composição, o que equivaleria ao mineral baileychlore. Por sua vez, a fluorita é corroída por minerais amarelos, que foram identificados por difratometria de raios $\mathrm{X}$ como ilita e caulinita.

A criolita é encontrada apenas no AGN. Pode ser magmática, como demonstrado pelos contatos retos com os minerais magmáticos, e hidrotermal com contatos corrosivos (Bastos Neto et al., 2009), da mesma maneira que o quartzo tardio, com proporções modais variáveis até chegar a ser o mineral mais importante (Figura 3F) e formar bolsões. A criolita de origem hidrotermal apresenta inclusões fluidas bifásicas aquosas primárias (Ronchi et al., 2011).

O zircão está associado com a fase magmática, com a qual possui contatos não reativos e é corroído pela matriz quartzo-feldspática. Pode apresentar tamanhos muito variados até milimétricos e, nos maiores, um núcleo mais escuro e bordas mais claras com cores de interferência marcadamente diferentes (Figuras 4E e 4F). Apresenta muitas inclusões de albita, feldspato potássico, cassiterita, quartzo e óxidos de ferro, identificados ao MEV, que lhe conferem textura em peneira e evidenciam seu caráter intermediário a tardio na paragênese magmática.

O pirocloro é acessório, possui tamanhos que variam de 100 a $200 \mu \mathrm{m}$ e ocorre nos interstícios da albita, eventualmente com contatos retilíneos e circundado pelo quartzo e pelo plagioclásio. É comum a presença de columbita e fluocerita associadas ao pirocloro. A columbita possui tamanhos que variam de 100 a $200 \mu \mathrm{m}$ e mantém o hábito semelhante ao do pirocloro próximo ao seu contato. $\mathrm{Na}$ subfácies $\mathrm{AGB}$, o pirocloro não é tão evidente, ocorre com menor frequência, mas seus aspectos texturais não diferem dos observados no AGN. Os cristais de pirocloro possuem cor amarelada e estão associados à columbita, que é opaca. Ao microscópio óptico, este contato é corrosivo (Figura 6A). Nas imagens obtidas por MEV na porção opaca, não é possível definir o tipo de contato, visto que o pirocloro parece possuir contatos com a columbita, que são marcados pelo processo de substituição do mineral; da mesma forma, ocorre entre os contatos da columbita com a fluocerita (Figura 6B). A fluocerita ocorre nos limites das bordas dos grãos de columbita e preenche interstícios do pirocloro e da matriz. O processo de columbitização é proveniente do aumento na vacância do sítio A do pirocloro, resultando na sua desestabilização e transformação para columbita, que tem assinaturas geoquímicas de $\mathrm{Sn}$ e U herdadas do pirocloro (Minuzzi et al., 2006; Pires et al., 2006). No pirocloro, paralelamente ao empobrecimento em $\mathrm{Pb}$, ocorreu enriquecimento em $\mathrm{Ca}, \mathrm{F}, \mathrm{Ce}$ e $\mathrm{Sn}$ e empobrecimento em Fe (Minuzzi et al., 2006).

\section{Geoquímica}

Os resultados analíticos de 17 amostras de AGN e AGB com diferentes graus de alteração hidrotermal, analisadas para elementos maiores, menores e traço, incluindo elementos terras raras (ETR), são apresentados na Tabela 2.

Apesar das alterações hidrotermais registradas em proporções muito variadas, o que cria uma grande dispersão de pontos nos diagramas da Figura 7 (Harker, 1909), as amostras do AGN mantêm seu caráter peralcalino, relativamente deficiente em alumina e com excesso de álcalis, compatível com a presença de riebeckita, ao passo que o AGB possui caráter mais rico em alumínio do que sódio e potássio, isto é, peraluminoso a metaluminoso (Figuras 7 e 8), e é caracterizado pela presença de mica verde rica em ferro e polilitionita. O AGB marrom-avermelhado com restos de mica verde oxidada apresenta teores menores de ferro do que o AGNc, por sua vez caracterizado por proporções 

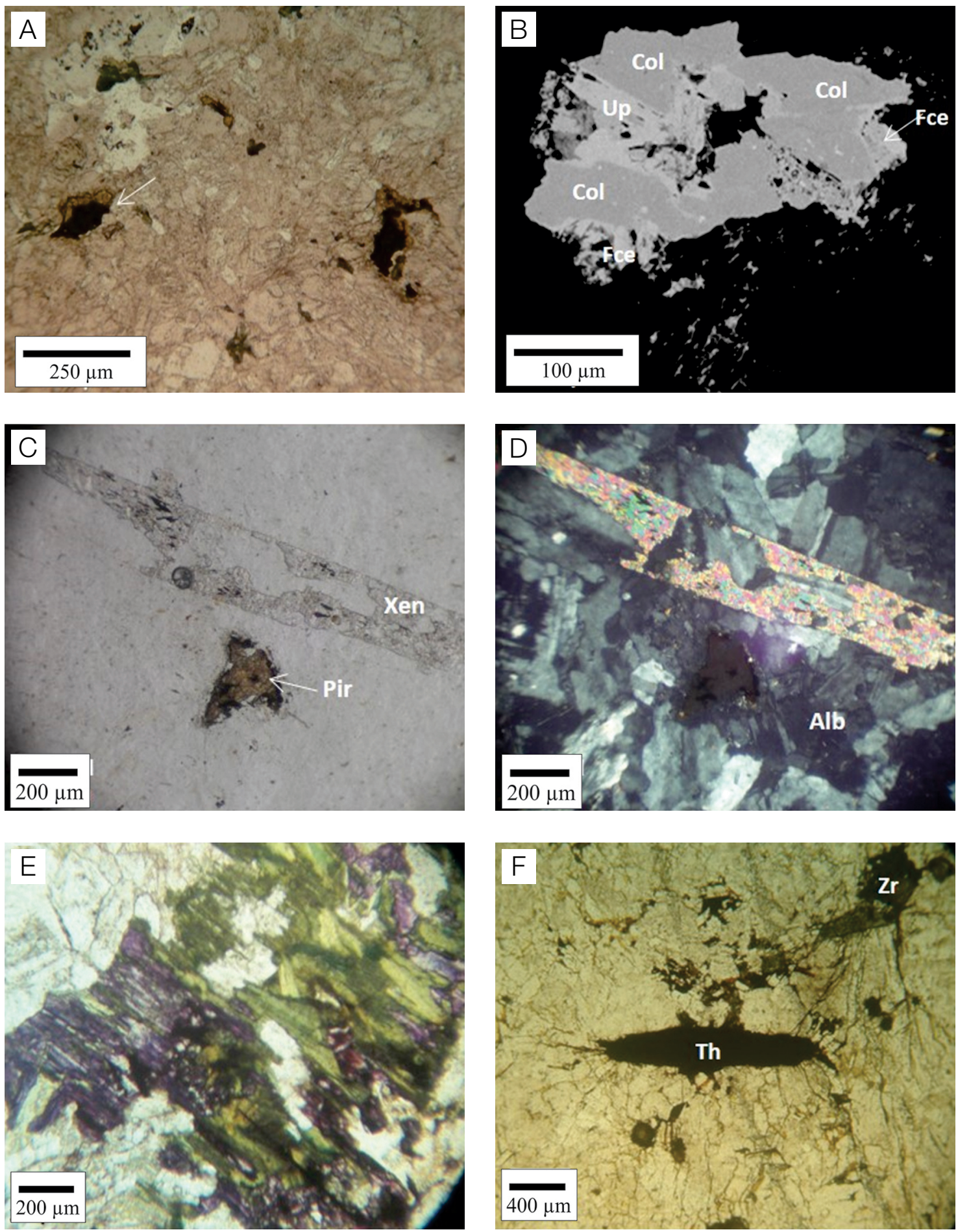

Col: pirocloro columbitizado; Fce: fluocerita; Up: U-Pb pirocloro; Pir: pirocloro; Xen: xenotima; Alb: matriz albítica com quartzo; Th: torita; Zr: zircão.

Figura 6. Minerais com elementos terras raras no albita granito. (A) A seta indica o cristal de U-Pb pirocloro alterado, conforme imagem de microscopia eletrônica de varredura em B, em luz polarizada não analisada (amostra AGB 2); (B) imagem de microscopia eletrônica de varredura de U-Pb pirocloro alterado para fluocerita e columbita; (C) xenotima e pirocloro corroídos pela matriz albítica do albita granito de núcleo cinza (amostra AGN 1), em luz polarizada não analisada; (D) xenotima e pirocloro corroídos pela matriz albítica do albita granito de núcleo cinza (amostra AGN 1), em luz polarizada analisada; (E) fluorita roxa e clorita substituindo a mica verde no albita granito de borda (amostra AGB 1); (F) albita granito de núcleo localmente avermelhado com torita com fraturas radiais preenchidas por óxidos de ferro relacionados à alteração hidrotermal (AGM 4B). 


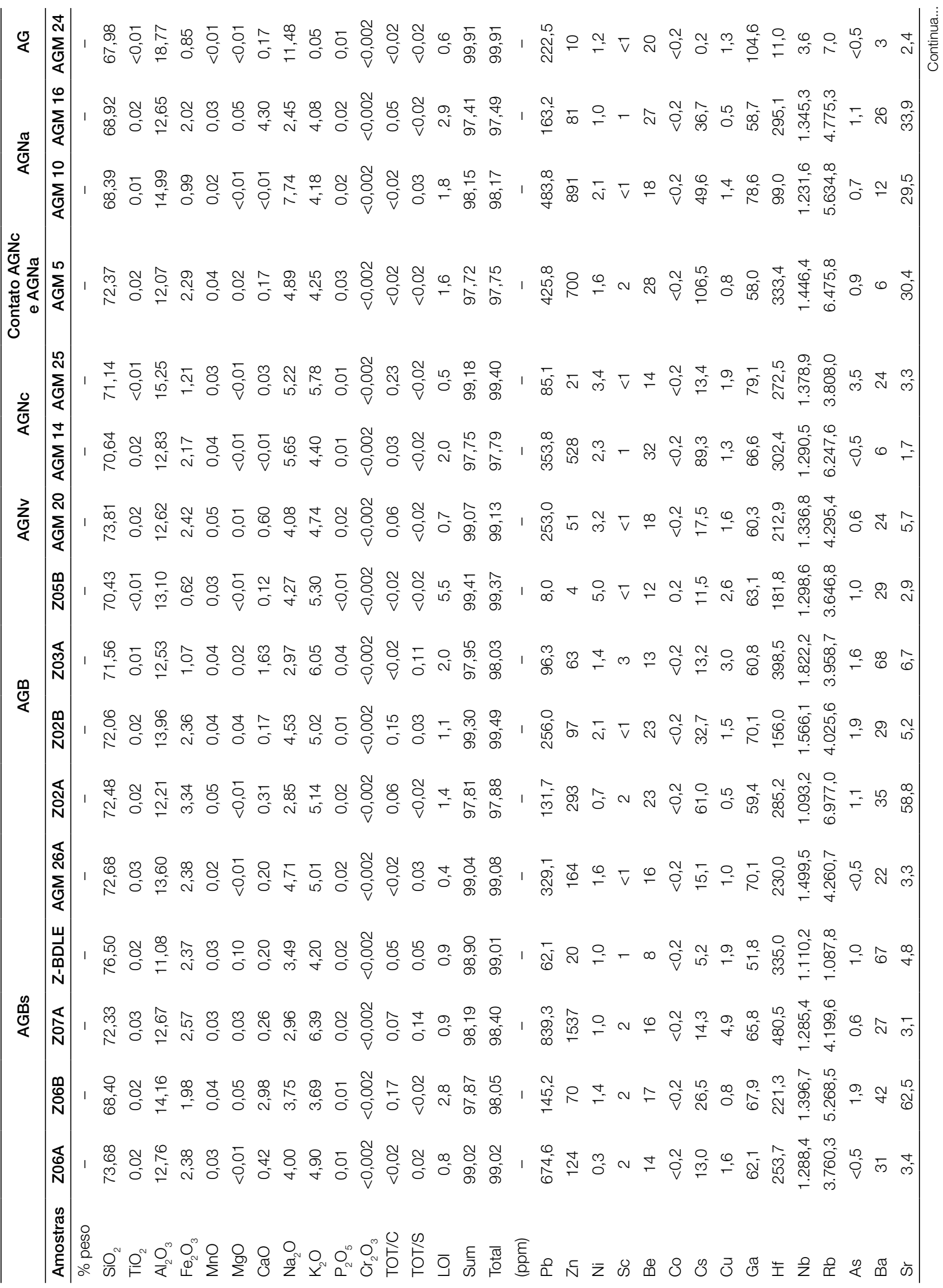




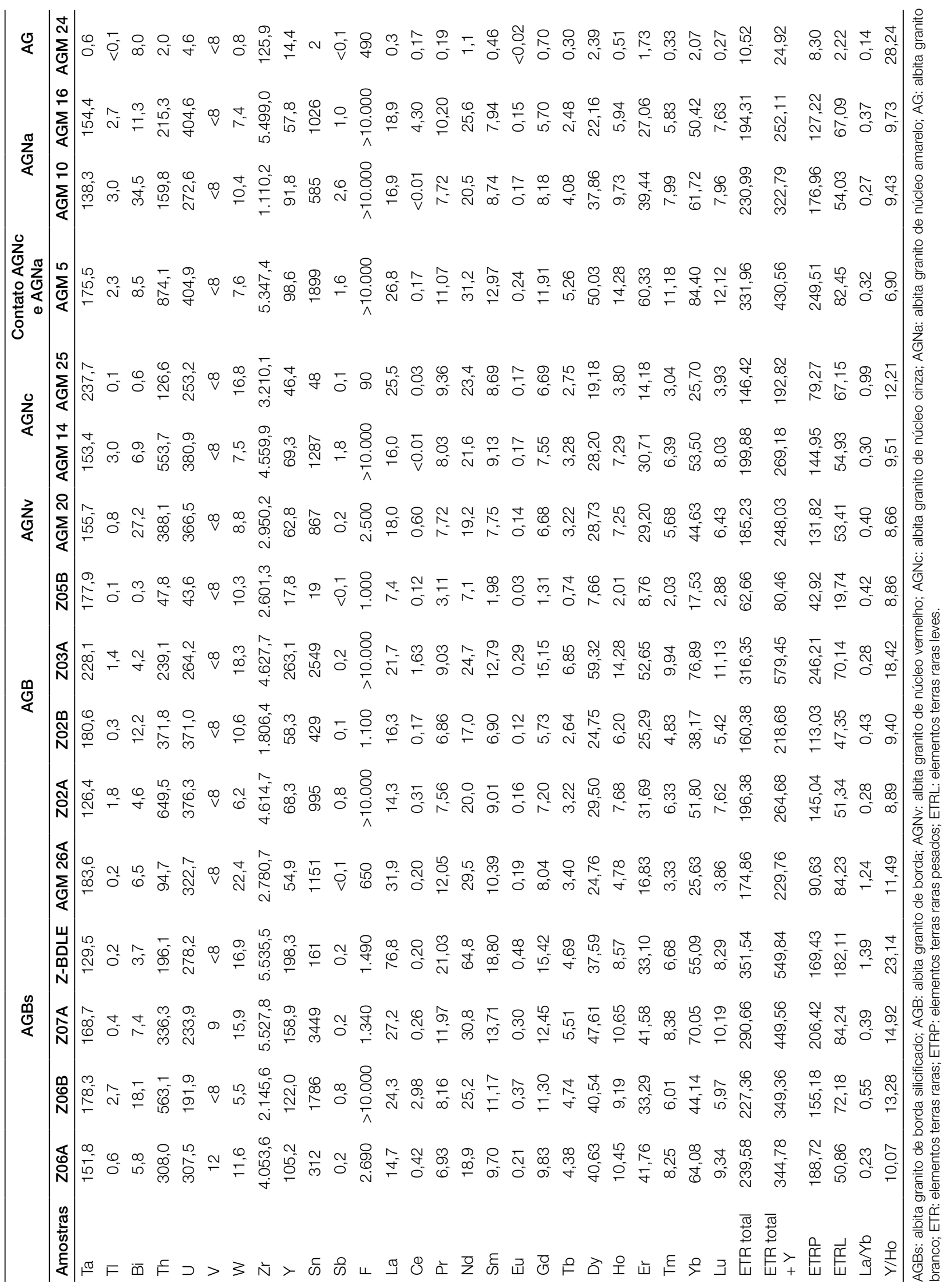


maiores de minerais máficos do que o AGB vermelho, marcado pela presença de clorita e fluorita. Os teores de sódio grosseiramente parecem diminuir do AGNc para o AGB e aumentam significativamente no AG branco, ao passo que o potássio aumenta do AGN para o AGB. Da mesma maneira, a diminuição em sódio (do AGN para o AGB) e o aumento em potássio correspondem a um aumento em sílica. Os teores de cálcio e magnésio são caracteristicamente muito baixos (Figura 7). As amostras cujas análises apresentam elementos com teores abaixo do nível de detecção, em especial o magnésio, foram apenas registradas nos diagramas e aparecem sobre o eixo horizontal com valor zero. O flúor concentra-se, principalmente, nas subfácies AGB, AGNc e AGNa.
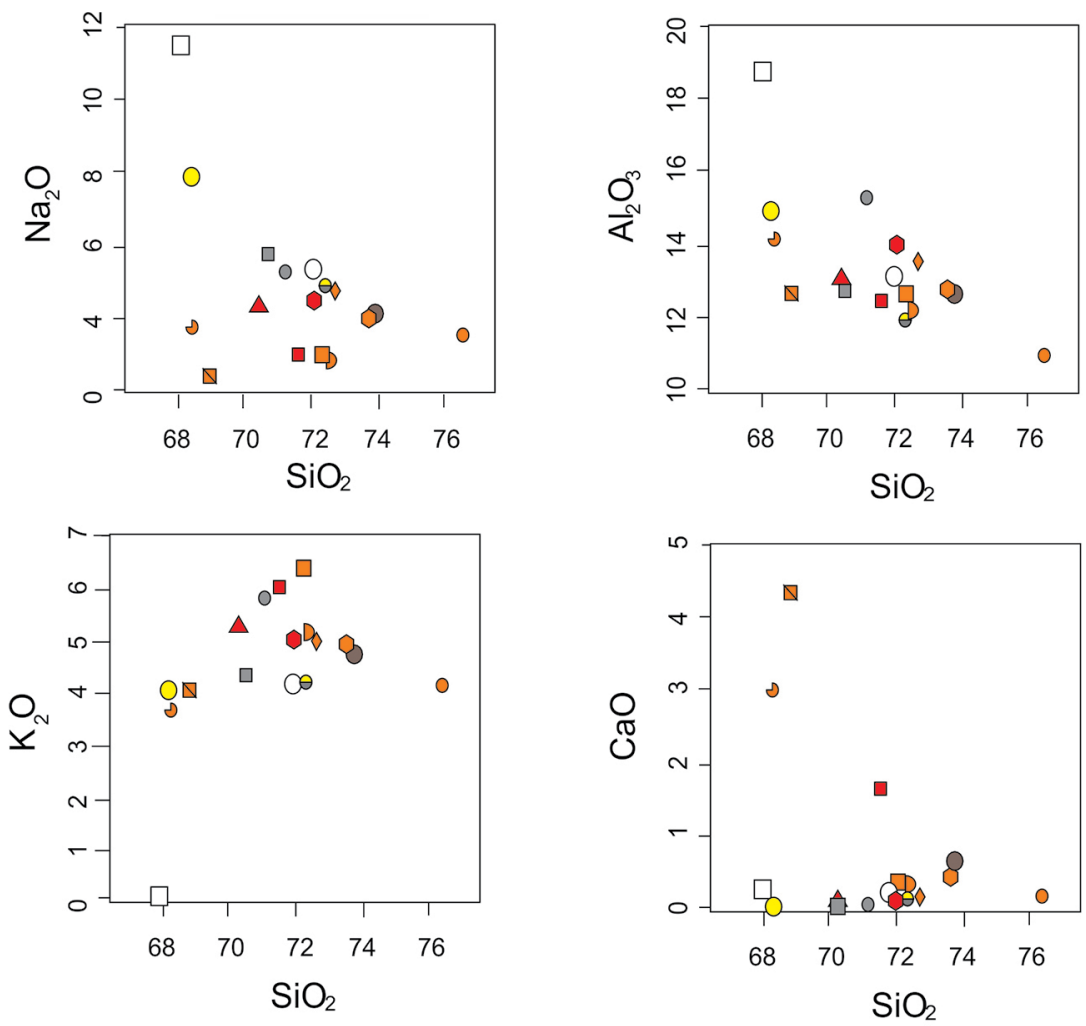

\begin{tabular}{|c|c|}
\hline \multicolumn{2}{|c|}{$\begin{array}{c}\text { Amostras subfácies } \\
\text { albita granito de borda }\end{array}$} \\
\hline \multirow{4}{*}{ AGBs } & D Z02A \\
& 0 Z06A \\
& $\square$ Z06B \\
& $\square$ Z07A \\
& $\square$ AGM 16 \\
& $\searrow$ AGM-26A \\
\hline \multirow{4}{*}{ AGB } & $\square$ Z02B \\
& $\square$ Z03A \\
& $\triangle$ Z05B \\
\hline
\end{tabular}
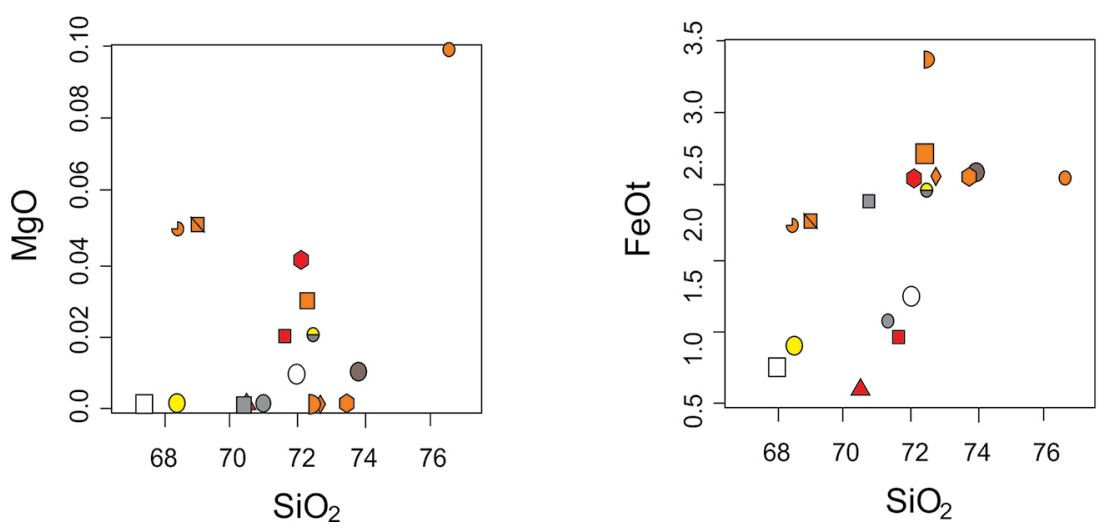

\begin{tabular}{|c|c|}
\hline \multicolumn{2}{|c|}{$\begin{array}{c}\text { Amostras subfácies } \\
\text { albita granito de núcleo }\end{array}$} \\
\hline AG & $\begin{array}{l}\text { O AGM 4B } \\
\square \text { AGM 24 }\end{array}$ \\
\hline AGNa & ○ AGM 10 \\
\hline $\begin{array}{c}\text { Contato } \\
\text { AGNc/AGNa }\end{array}$ & $\ominus$ AGM 5 \\
\hline AGNv & ○ AGM 20 \\
\hline AGNc & ○ AGM 14 \\
\end{tabular}

AGBs: subfácies albita granito de borda silicificado; AGB: albita granito de borda; AG: albita granito branco; AGNa: albita granito de núcleo amarelo; AGNv: albita granito de núcleo vermelho; AGNc: albita granito de núcleo cinza.

Figura 7. Diagrama bivariante aplicado às subfácies albita granito de borda e albita granito de núcleo. A seta avermelhada representa as variações composicionais do albita granito de borda e da subfácies albita granito de borda silicificado; a seta preta, as variações composicionais do albita granito de núcleo branco, do albita granito branco, do albita granito de núcleo amarelo, do albita granito de núcleo vermelho e do albita granito de núcleo cinza (Harker, 1909). 
Os padrões de distribuição dos ETR nos diagramas normalizados ao condrito (McDonough e Sun, 1995) para o AGN e o AGB indicam enriquecimento em elementos terras raras pesados (ETRP), visto que a razão La/Yb nas amostras representativas possui média igual a 0,5 para ambas as subfácies.

A subfácies AGN apresenta valores médios de $260 \mathrm{ppm}$, um pouco menores do que a média do AGB (297 ppm de ETRtotal), ao passo que o valor ETRtotal do AG branco (albitização) é nitidamente menor, com 10,5 ppm.

A anomalia negativa de Eu é bem pronunciada, sendo a média da razão $\mathrm{Eu}^{(\mathrm{AGN})} / \mathrm{Eu}^{(\mathrm{AGB})}$ igual a 0,68 ; neste caso, a dispersão no diagrama de distribuição dos ETR é considerável, sendo que o $\mathrm{AGN}$ possui uma anomalia de Eu maior em relação ao AGB.

Comparando os padrões de distribuição dos ETR (Figura 9), observa-se que AGB forma um conjunto caracterizado pelo enriquecimento relativo em elementos terras raras leves (ETRL), enquanto no AGN se observa o enriquecido em ETRP, conferindo padrão levemente crescente. O padrão de ETR dos corpos afaníticos brancos (AG branco) é similar ao padrão do AGB e do AGN, porém com a soma total de ETR menor, sugerindo cogeneticidade.

\section{Inclusões fluidas}

Os fenocristais de quartzo com tamanhos variados de 1,8 a $4 \mathrm{~mm}$ possuem três situações em que são encontradas inclusões fluidas (Figura 10). A primeira, eventualmente em forma piramidal, marcando linhas de crescimento do quartzo com inclusões primárias (Figura $10 \mathrm{~A}-1$ ), bifásicas aquosas, tamanhos de 5 a $25 \mu \mathrm{m}$, e inclusões monofásicas escuras gasosas associadas em menor frequência.
A segunda situação é em trilhas de inclusões com aspecto arborescente, pseudo-secundárias, também bifásicas aquosas associadas com monofásicas escuras gasosas, com tamanhos em torno de $5 \mu \mathrm{m}$ (Figura 10B - 2). E, por último, em trilhas de inclusões secundárias, monofásicas claras aquosas com distribuição radial em torno de um mineral opaco (Figura 10A - 2).

$\mathrm{O}$ veio de quartzo possui uma porção de cor branca e outra hialina, ambas aleatoriamente distribuídas na amostra. As inclusões encontradas na porção hialina são predominantemente primárias, bifásicas aquosas, com tamanhos de 5 a $15 \mu \mathrm{m}$, e marcam a linha de crescimento do mineral. Na porção de cor branca, as inclusões também são predominantemente primárias, bifásicas aquosas e por vezes ocorrem inclusões primárias, trifásicas de alta salinidade. Com menor frequência em relação às inclusões primárias, foram observadas inclusões secundárias em ambas as porções, bifásicas aquosas, com tamanhos de 10 a $20 \mu \mathrm{m}$, e que marcam o preenchimento de fraturas no mineral.

As temperaturas de homogeneização total do fluido aquoso das inclusões fluidas primárias, secundárias e pseudo-secundárias, observadas nas amostras de fenocristais e veio de quartzo, são similares e variam de 98 a $295^{\circ} \mathrm{C}$, enquanto as temperaturas de fusão variam de $-1 \mathrm{a}-22^{\circ} \mathrm{C}$, divididas em três grupos principais de salinidade: um com valores entre 0,5 e $5 \%$ peso eq. $\mathrm{NaCl}$; outro entre 10 e $14 \%$ peso eq. $\mathrm{NaCl}$; e o terceiro entre 16 e $23 \%$ peso eq. $\mathrm{NaCl}$ (Figuras 11 e 12). Além disso, foi possível observar inclusões fluidas primárias trifásicas (sólido halita + líquido + gás) com salinidade de $26 \%$ peso eq. $\mathrm{NaCl}$.

A correlação horizontal grosseira da temperatura de homogeneização e salinidade das inclusões fluidas primárias e pseudo-secundárias do quartzo tardio, tanto no veio

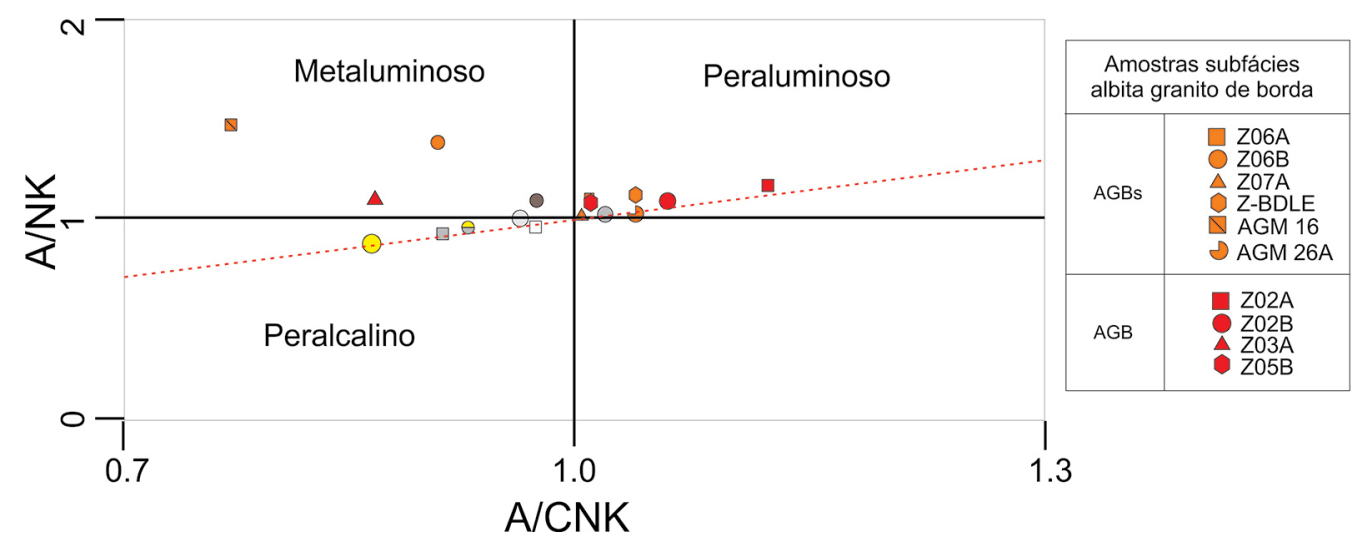

\begin{tabular}{|c|c|}
\hline \multicolumn{2}{|c|}{$\begin{array}{c}\text { Amostras subfácies } \\
\text { albita granito de núcleo }\end{array}$} \\
\hline AGNb & $\bigcirc$ AGM 4B \\
\hline AG & $\square$ AGM 24 \\
\hline AGNa & $\bigcirc$ AGM 10 \\
\hline $\begin{array}{c}\text { Contato } \\
\text { AGNc/AGNa }\end{array}$ & $\ominus$ AGM 5 \\
\hline AGNv & $\bigcirc$ AGM 20 \\
\hline AGNc & $\square$ AGM 14 \\
& AGM 25 \\
\hline
\end{tabular}

AGBs: subfácies albita granito de borda silicificado; AGB: albita granito de borda tradicional; AGNb: albita granito de núcleo branco; AG: albita granito branco; AGNa: albita granito de núcleo amarelo; AGNv: albita granito de núcleo vermelho; AGNc: albita granito de núcleo cinza.

Figura 8. Diagrama $A / N K$ versus $A / C N K$ aplicado às variações das subfácies albita granito de borda e albita granito de núcleo (Shand, 1943). 


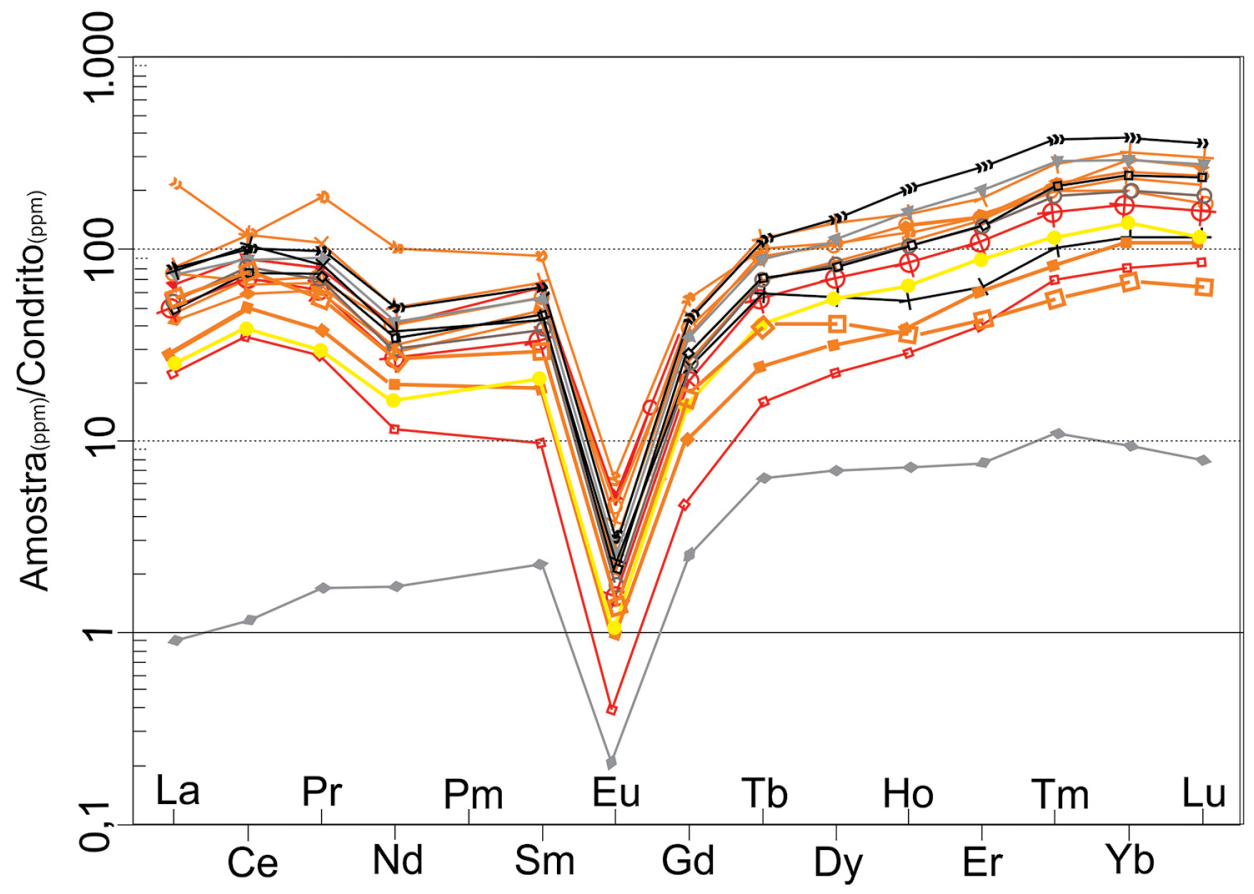

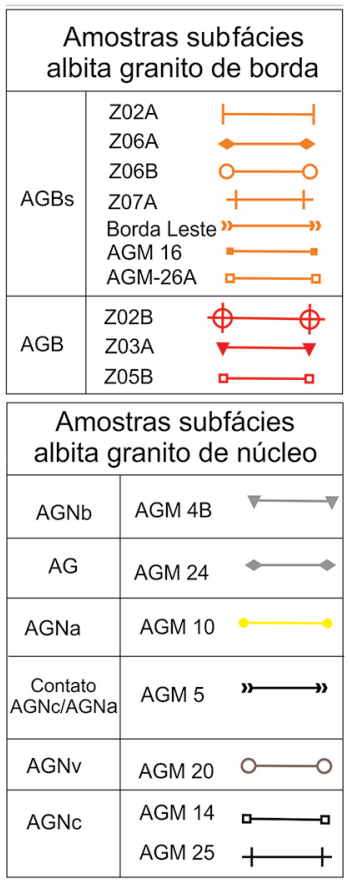

AGBs: subfácies albita granito de borda silicificado; AGB: albita granito de borda tradicional; AGNb: albita granito de núcleo branco; AG: albita granito branco; AGNa: albita granito de núcleo amarelo; AGNv: albita granito de núcleo vermelho; AGNc: albita granito de núcleo cinza.

Figura 9. Padrão elementos terras raras das variações das subfácies albita granito de borda e albita granito de núcleo.

A
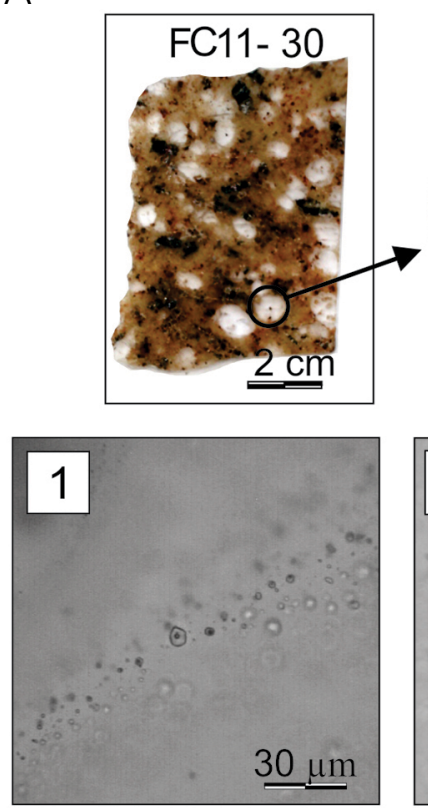
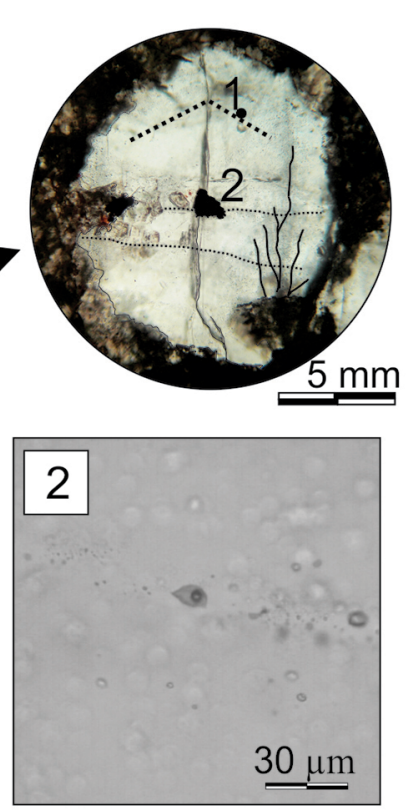

B
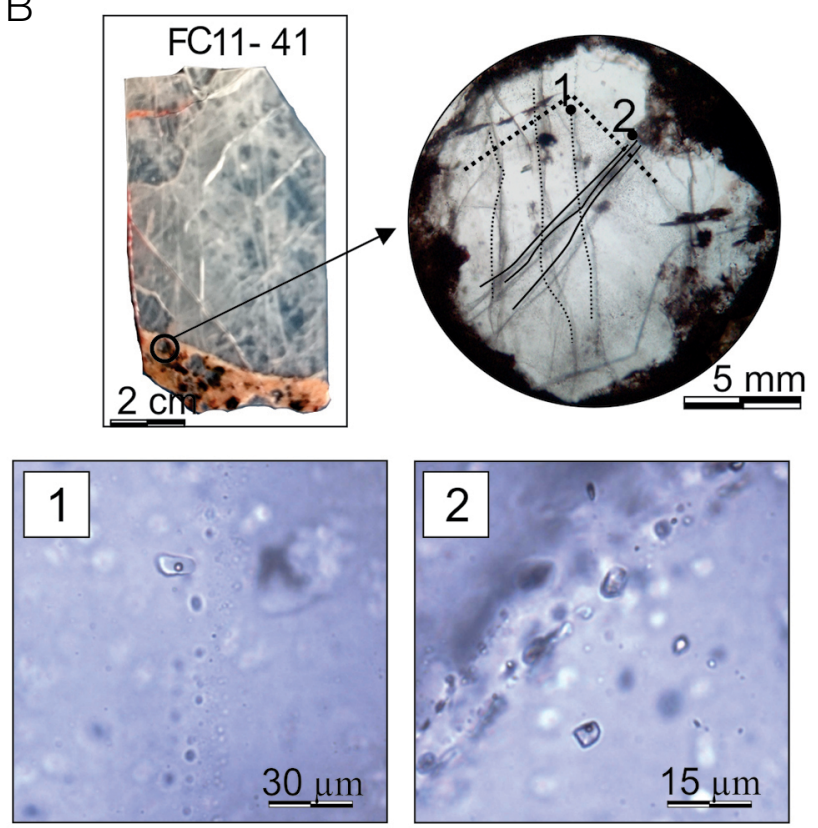

Figura 10. (A) Foto da lâmina bipolida e fotomicrografia de inclusões fluidas do albita granito de núcleo; 1 - inclusões fluidas em linhas de crescimento do quartzo tardio com aspecto de fenocristal; 2 - inclusões fluidas em trilhas cortando mineral opaco; (B) foto da lâmina bipolida e fotomicrografia de inclusões fluidas do albita granito de núcleo em cristal de quartzo com aspecto de fenocristal próximo ao contato com o veio de quartzo; 1 - inclusões fluidas secundárias; 2 inclusões fluidas pseudo-secundárias em trilhas arborescentes. 
quanto naquele com aspecto de fenocristal, corresponde ao descrito por Bastos Neto et al. (2009) para as inclusões fluidas primárias na criolita, indicando tratar-se do mesmo fluido mineralizante para as duas fases minerais. A ampla variação de salinidade até valores de $26 \%$ peso eq. $\mathrm{NaCl}$, indicados pela presença de pequeno cristal de saturação de halita, sugere fluido magmático.

\section{DISCUSSÃO}

O AGNc, não alterado, é caracterizado por uma paragênese magmática precoce quartzo-fedspática com até $10 \%$ de minerais máficos, notavelmente uma mica verde rica em ferro, o anfibólio riebeckita que é compatível com seu caráter peralcalino, o zircão e a polilitionita, entre outros. Essa paragênese porfirítica precoce é corroída por uma matriz magmática branca tardia essencialmente composta por quartzo, albita e feldspato potássico, preservando os fenocristais. Tanto o AGB marrom-avermelhado, como o vermelho, apresenta essa mesma associação de minerais magmáticos, sem riebeckita devido ao seu caráter metaluminoso a peraluminoso. Porém, pseudomorfos da mica verde rica em ferro, substituída ora por óxidos de ferro, na porção marrom avermelhada, ora por fluorita e clorita ou argila amarela nas porções vermelhas e texturas como golfos de corrosão, sugerem processos de alteração hidrotermal deutérica ou, conforme Costi (2000), autometassomática.

Tanto o AGN quanto o AGB são cortados ou corroídos por uma fase afanítica branca tardia composta essencialmente de albita, quartzo e traços de criolita ou fluorita, sem feldspato potássico e sem indícios da presença de minerais da fase magmática precoce, exceto alguns cristais corroídos de zircão. Essa fase, aqui denominada de AG branco afanítico, é resultado de um processo de albitização, difere da matriz albítica do AGN pelo conteúdo total menor em terras raras e ausência de feldspato potássico. A albita chessboard, considerada como resultado de albitização, ocorre apenas na matriz do AGN cinza, indicando seu caráter parcialmente hidrotermal/metassomático.

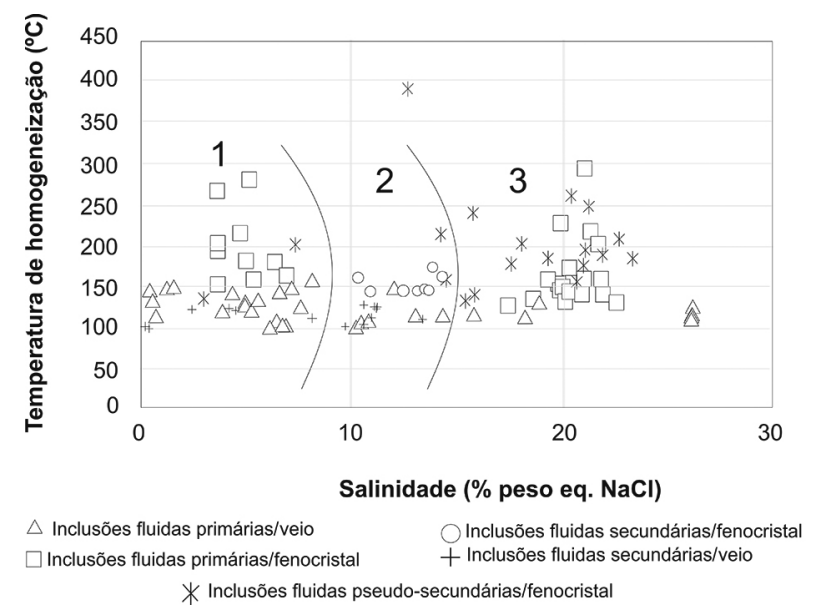

Figura 12. Variação da temperatura de homogeneização e salinidade dos diversos tipos de inclusões fluidas encontradas no quartzo tardio com aspecto de fenocristal e também em veio.
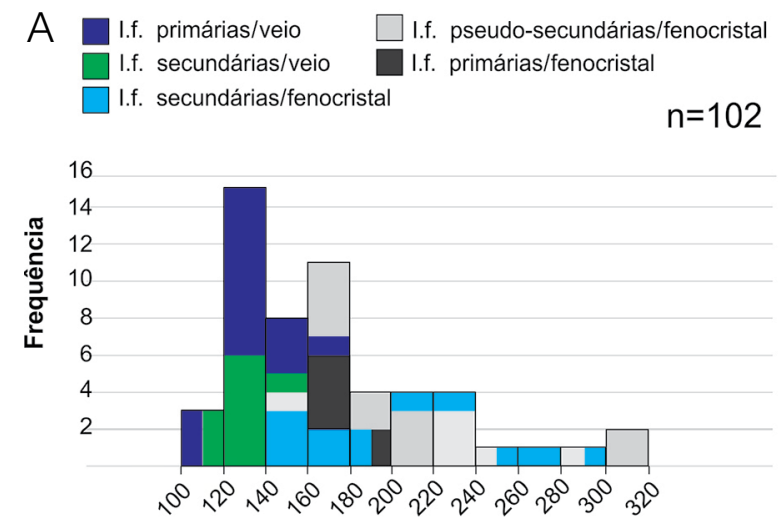

Temperatura de homogeneização $\left({ }^{\circ} \mathrm{C}\right)$

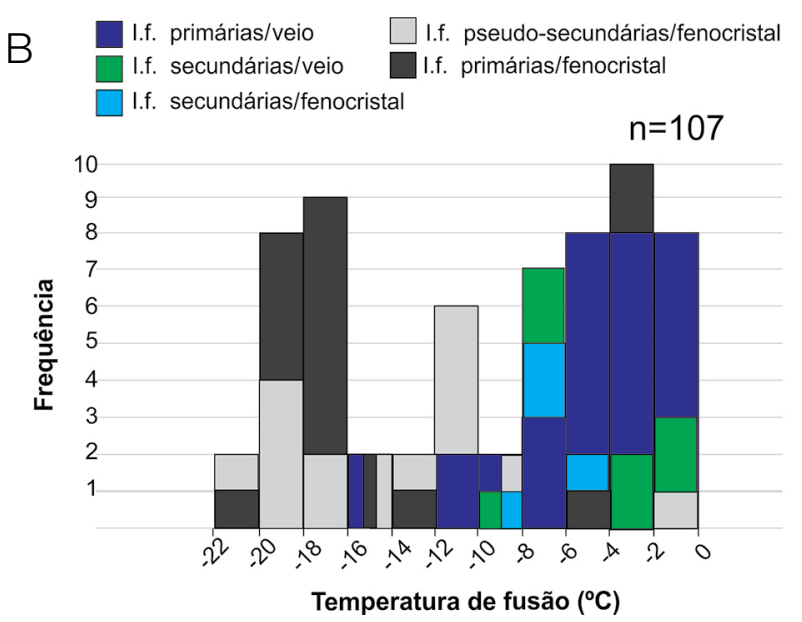

I.f.: inclusões fluidas.

Figura 11. Histogramas. As colunas de menor espessura representam a mesma frequência de inclusões fluidas de diversos tipos. A letra (n) representa o total de medidas realizadas. (A) Variação de temperatura de homogeneização; (B) fusão final do gelo de inclusões fluidas do quartzo tardio. 
Quando há o predomínio de quartzo como fenocristal no AGB e no AGN, as proporções modais de quartzo são maiores do que a soma de albita e microclínio e tendem a migrar de campos de classificação do monzogranito a granitoides ricos em quartzo. Em amostras em que predomina a matriz albítica, a composição dos granitos tende a migrar de monzogranitos a tonalitos. Embora menos evidente, devido à dispersão dos pontos, mas de maneira coerente, o aumento de $\mathrm{SiO}_{2}$ correspondente à silicificação do AGB ocorre paralelamente a uma diminuição em $\mathrm{Na}_{2} \mathrm{O}$ e aumento de $\mathrm{K}_{2} \mathrm{O}$ (Figura 7).

Aparentemente, a presença de quartzo ou albita tardios deveria afetar a classificação modal das rochas, entretanto, pode-se observar que, em geral, quando há o enriquecimento de quartzo nas amostras, também há enriquecimento de plagioclásio, mantendo proporções similares. Neste caso, quando classificados pelo sistema IUGS (Streckeisen, 1967), incluindo ou não o quartzo e albita tardios, os resultados pouco variaram em seus respectivos campos de classificação, o que indica que mesmo com um possível enriquecimento de quartzo e de albita, provenientes dos processos de silicificação e albitização, o AGB e o AGN não sofreram grandes variações em sua composição mineralógica essencial, ou seja, a rocha que foi classificada, por exemplo, como monzogranito, considerando apenas os minerais aparentemente magmáticos, continua sendo classificada como monzogranito, se incluídos o quartzo e o albita aparentemente tardios. O AG (AGN e AGB) tem composição distinta das demais fácies do granito Madeira, o que é bem expressivo na análise dos elementos menores e traços, como Nb, Ta, Pb, Sn, Th, U, Zr, Y e ETR (Costi, 2000). A comparação do AGN com o AGB possibilitou concluir que existem muitos elementos com comportamento similar, porém ocorrem diferenças significativas, principalmente nos teores de $\mathrm{Na}$ e $\mathrm{F}$ menores no AGB e nos conteúdos de Y e ETRP, também relativamente menores no AGB. A maior parte dos padrões de distribuição dos ETR nas diferentes fácies apresenta sempre uma significativa anomalia negativa de $\mathrm{Eu}$; em duas amostras do AGB, o Ce tem anomalia positiva. A possibilidade de o flúor ser o único responsável pela complexação do Ce e causar esta anomalia deve ser cautelosamente avaliada, pois, embora o conteúdo médio de $\mathrm{F}$ no $\mathrm{AGN}$ seja quase o dobro que no AGB, não existe correlação entre esses elementos nessas subfácies.

As composições e as relações mineralógicas do AGB marrom-avermelhado e vermelho, AGNc e AGNb e AG branco (afanítico) revelam pelo menos duas paragêneses magmáticas e diversos processos hidrotermais precoces e tardios. Principalmente no AGB, parte importante dos cristais grandes de quartzo é tardio, límpido, intersticial entre os minerais precoces e possui inclusões fluidas bifásicas aquosas. Esse quartzo pode representar um importante evento tardio resultante da circulação de fluidos da transição magmático-hidrotermal. A paragênese magmática precoce é representada pelos minerais em equilíbrio textural com os fenocristais, e a tardia corresponde aos minerais da matriz em contato reativo com a paragênese precoce. O feldspato alcalino é quase totalmente substituído por albita, em um processo de albitização que cria a albita chessboard. Essas variações mineralógicas e petrográficas são relacionadas à interação entre minerais da fase ortomagmática com fluidos hidrotermais, deutéricos, que criaram as fases silicificadas (quartzo tardio), albitizadas (chessboard), argilizadas, fluoritizadas, cloritizadas ou criolitizadas do AGN e do AGB, além de afetar os minerais magmáticos primários ricos em ETR.

$\mathrm{Na}$ escala do AG, a zonação marcada pelas duas subfácies AGN e AGB, em cujo limite se situa o afloramento estudado, corresponde também a uma zonação na distribuição espacial dos fluoretos hidrotermais disseminados na rocha, caracterizada pela presença de criolita no AGN e de fluorita no AGB. Assim, a zonação AGN-AGB pode ser, em parte, devida a gradientes químicos relacionados à migração de fluidos hidrotermais do centro para as bordas do AG, migração esta induzida por uma grande concentração de voláteis na parte central do corpo, consequência da cristalização concêntrica, da borda para o centro (Hildreth e Wilson, 2007).

O resfriamento da câmara magmática de fora para dentro criou, inicialmente, o AGB. Com o prosseguimento do processo, no início da fase hidrotermal precoce, uma exsolução de fluidos deutéricos pode ter sido responsável pelo processo de autometassomatismo (Costi, 2000) marcado pela oxidação do ferro visível em minerais como a mica verde rica em ferro, gerando o AGB marrom-avermelhado. No estágio seguinte, ocorreu a cristalização do AGNc. A concentração de voláteis no magma era alta, especialmente de F, tendo ocorrido a cristalização de criolita disseminada ao longo de todo o estágio magmático (criolita precoce incluída em fenocristais de quartzo com textura snowball e criolita disseminada na matriz do AGN, correspondendo à criolita I de Bastos Neto et al. 2009). Localmente, as texturas apresentadas pela criolita magmática tardia sugerem que possa ter ocorrido processo do tipo esponja de minerais (crystal mush). Na transição magmático-hidrotermal ocorreu a exsolução de fluidos hidrotermais ricos em $\mathrm{F}$, responsáveis pela formação do depósito de criolita maciça e pela criolita hidrotermal disseminada, a criolita II (Bastos Neto et al., 2009), com a qual os minerais primários apresentam feições de corrosão nos contatos, contrariamente à criolita I, que está em equilíbrio com os minerais primários.

A fase magmática mais tardia identificada neste estudo corresponde ao $\mathrm{AGNb}$ porfirítico. Esta rocha ocorre principalmente no AGN, mas também afeta o AGB. Em ambos, ela 
substitui gradativamente a rocha original, porém mantendo a textura porfirítica em uma matriz albítica fina e branca. Uma possível explicação para essa feição seria a formação dessa rocha ser relacionada à expulsão por filter pressing (Winter, 2001) de um fluido magmático presente dentro da esponja de minerais do AGN. Subsequentemente, fluidos aquosos deutéricos, correspondentes ao final da fase hidrotermal precoce, formam o AG branco afanítico (albitização), que pode ter fluorita ou criolita, e as diversas alterações hidrotermais que transformam o AGB marrom-avermelhado em vermelho, com as respectivas fases associadas de silicificação (quartzo tardio), que também afetaram o AGNc. Finalmente, o hidrotermalismo mais tardio foi responsável pela cloritização, fluoritização e/ou argilização, principalmente no AGB, mas também no AGN. Os minerais ricos em Fe do AGN localmente desaparecem dando lugar a óxidos de ferro, criando manchas avermelhadas, eventualmente, no entorno de fraturas.

O estudo de inclusões fluidas descritas em fenocristais e veio de quartzo da sub-fácies AGN permitiu caracterizar o fluido hidrotermal deutérico exsolvido durante o processo de transição magmático-hidrotermal (Ronchi et al. 2005; Bastos Neto et al., 2009). Os fenocristais de quartzo, que caracterizam a textura porfirítica do AG, são de origem magmática, porém alguns deles apresentam inclusões fluidas aquosas primárias e pseudo-secundárias de temperatura relativamente baixa $\left(<250^{\circ} \mathrm{C}\right)$ e salinidade até $26 \%$ peso eq. $\mathrm{NaCl}$. O estudo de inclusões fluidas em minerais da parte central do AG, notadamente na criolita e no quartzo do depósito de criolita maciça (Ronchi et al., 2011), mostra que o hidrotermalismo iniciou em temperaturas da ordem de $400^{\circ} \mathrm{C}$. O início da formação do depósito de criolita maciça foi atribuído à transição magmático-hidrotermal (Bastos Neto et al., 2009). A cristalização da criolita maciça prosseguiu até temperaturas da ordem de $100^{\circ} \mathrm{C}$, tendo a participação de soluções meteóricas ocorrido apenas no estágio mais tardio. Ou seja, paralelamente à formação do depósito de criolita maciça na parte central do AGN, as demais partes do AG foram afetadas pelos processos de alteração deutérica aqui descritos.

\section{CONCLUSÕES}

O AG em Pitinga, seja por suas mineralizações em estanho, metais raros e flúor ou por sua complexidade mineralógica, despertou muita atenção no meio científico especializado. Muitos trabalhos competentes e detalhados foram publicados estabelecendo um quadro bastante complexo. Entretanto, o estudo de detalhe do contato entre o AGB e o AGN na porção norte do corpo granítico revelou alguns aspectos inéditos que resultam de alterações hidrotermais deutéricas e permitem apresentar novas informações sobre a evolução dessa rocha. Essencialmente, tais processos se relacionam à transição magmático-hidrotermal representada pelas fases magmáticas precoce (paragênese dos fenocristais) e tardia (paragênese afaníticada matriz), e hidrotermal precoce (mica verde oxidada no AGB marrom-avermelhado e também localmente no AGN) em transição para uma fase hidrotermal tardia (clorita, fluorita, ilita e caolinita no AGB vermelho e localmente no $A G N$ ), além da albita fina (AG branco afanítico) que corta AGB e AGN.

É consenso que o resfriamento concêntrico, de fora para dentro, produziu inicialmente o AGB, com uma mineralogia similar ao AGN, exceto pela ausência de riebeckita. A cor vermelha do AGB e de partes do AGN resulta da oxidação do ferro presente em minerais como a mica verde. Os diferentes tons de vermelho na borda refletem paragêneses de alteração hidrotermal diferentes, isto é, o marrom-avermelhado devido à presença de óxidos de ferro finamente disseminados e com restos de mica verde e o AGB vermelho caracterizado pela presença de fluorita e clorita, substituindo e mantendo pseudomorfos da mica verde e/ou com presença de argilas, como ilita e caulinita. Adicionalmente, a textura porfirítica em ambas as subfácies de borda e de núcleo com uma matriz fina sugere um processo de queda de pressão, resfriamento e cristalização rápida dessa matriz, que se torna afanítica. Em casos de queda de pressão, o processo denominado de ebulição (first boiling) costuma provocar a exsolução de voláteis. A criolita e o quartzo intersticiais são texturas muito evidentes, ocorrem nas duas subfácies e constituem evidência da formação de uma esponja de minerais (crystal mush). No caso da formação de tal textura, o processo de filter pressing, no qual fluidos são expulsos da trama mineralógica já cristalizada e circulam pelo corpo granítico também já cristalizado, provocando alterações deutéricas, não é inesperado. Adicionalmente, corpos quartzo-feldspáticos afaníticos brancos, com ou sem fluorita ou criolita, aqui denominados AG branco, ocorrem cortando de maneira discordante todas as fases anteriores, representando uma fase final de albitização. Dessa maneira, torna-se claro que a identificação de subfácies e alterações deutéricas permitem supor uma evolução da câmara inicialmente magmática, em processo de transição magmático-hidrotermal, com exsolução de fluidos e voláteis em um momento de queda de pressão e ebulição, responsáveis pela diversidade mineralógica descrita.

\section{AGRADECIMENTOS}

Os autores agradecem ao Conselho Nacional de Desenvolvimento Científico e Tecnológico (CNPq) (Projeto nº 405839/2013-8). 


\section{REFERÊNCIAS}

Bastos Neto, A. C., Pereira, V. P., Lima, E. F., Ferron, J. M., Minuzzi, O., Ronchi, L. H., Flores, J. A. A., Frantz, J. C., Pires, A. C., Pierosan, R., Hoff, R., Botelho, N. F., Rolim, S. B. A., Rocha, F. N. F. U., Ulmann, L. (2005). A jazida de criolita da Mina Pitinga (Amazonas). In: ABIMB (Ed.), Caracterização de depósitos minerais em distritos mineiros da Amazônia (481-552). Brasília: DNPM/FINEP/ADIMB.

Bastos Neto, A. C., Pereira, V. P., Ronchi, L. H., Lima, E. F., Frantz, J. C. (2009). The world class Sn, Nb, Ta, F (Y, REE, Li) deposit and the massive cryolite deposit associated with the albite-enriched facies of the Madeira A-type granite, Pitinga mining district, Amazonas State, Brazil. The Canadian Mineralogist, 47(6), 1329-1357. https://doi. org/10.3749/canmin.47.6.1329

Bates, R. L., Jackson, J. A. (1987). Glossary of Geology. $3^{\mathrm{a}}$ ed. Alexandria: American Geological Institute. $788 \mathrm{p}$.

Bodnar, R. J. (2003). Introduction to aqueous-electrolyte fluid inclusions. In: I. Samson, A. Anderson, D. Marshall (Eds.). Fluid Inclusions - Analysis and Interpretation (32, 81-100). Vancouver: Mineralogical Association of Canada Short Course Series.

Burnham, C. W. (1997). Magmas and hydrothermal fluids. In: H. L. Barnes (Ed.), Geochemistry of hydrothermal ore deposits, 63-123. $3^{\mathrm{a}}$ ed. Nova York: John Wiley \& Sons.

Cathelineau, M., Marignac, C., Dubessy, J., Poty, B., Weisbrod, A., Ramboz, C., Leroy, J. (1988). Fluids in granitic environment. Rendiconti della Societa Italiana di Mineralogia e Petrologia, 42-43, 263-274.

Cobbing, J. (2000). The geology and mapping of granite batholiths. Berlin: Springer, 141 p. https://doi. org/10.1007/3-540-45055-6

Costi, H. T. (2000). Petrologia de granitos alcalinos com alto flúor mineralizados em metais raros: o exemplo do Albita-granito da Mina Pitinga, Amazonas, Brasil. 345p. Tese (Doutorado). Belém: Curso de Pós-Graduação em Geologia e Geoquímica - UFPA.

Costi, H. T., Dall'Agnoll, R., Moura, C. A. V. (2000). Geology and $\mathrm{Pb}-\mathrm{Pb}$ Geochronology of Paleoproterozoic Volcanic and Granitic Rocks of Pitinga Province, Amazonian Craton, Northern Brazil. International Geology Review, 42(9), 832-849. https://doi. org/10.1080/00206810009465114
Costi, H. T., Dall'Agnoll, R., Pichavant, M., Rämö, O. T. (2009). The peralkaline tin-mineralized madeira cryolite albite-rich granite of Pitinga, Amazonian Craton, Brazil: petrography, mineralogy and crystallization processes. The Canadian Mineralogist, 47(6), 1301-1327. https://doi. org/10.3749/canmin.47.6.1301

Costi, H. T., Régis, R. M. K., Dall'Agnoll, R. (2005). Depósitos de estanho da Mina Pitinga, Estado do Amazonas. In: ADIMB (Ed.), Caracterização de depósitos minerais em distritos mineiros da Amazônia. Brasília: DNPM/FINEP/ADIMB. 414 p.

Gill, R. (2014). Rochas e processos ígneos: um guia prático. Porto Alegre: Bookman. 427 p.

Harker, A. (1909). The natural history of igneous rocks. Nova York: McMillan. 384 p.

Hekinian, R. (1982). Deuteric Alteration. In: R. Hekinian (Ed.), Petrology of the ocean floor $(33,11,329-331)$. AmsterdanOxford-New York: Elsevier, Oceanography Series.

Helba, H., Trumbull, R. B., Morteani, G., Khalil, S. O. E., Arslan, A. (1997). Geochemical and Petrographic Studies of Ta Mineralization in the Nuweibe Albite Granite Complex, Egypt. Mineralium Deposita, 32(2), 164-179. https://doi. org/10.1007/s001260050082

Hildreth, W., Wilson, C. J. N. (2007). Compositional Zoning of the Bishop Tuff. Journal of Petrology, 48(5), 951-999. https://doi.org/10.1093/petrology/egm007

Horbe, M. A., Horbe, A. C., Costi, H. T., Teixeira, J. T. (1991). Geochemical characteristics of cryolite-tin-bearing granites from the Pitinga mine, northwestern Brazil - A Review. Journal of Geochemical Exploration, 40(1-3), 227-249. https://doi.org/10.1016/0375-6742(91)90040-2

Lenharo, S. L. R., Pollard, P. J., Born, H. (2003). Petrology and textural evolution of granites associated with tin and rare-metals mineralization at the Pitinga mine, Amazonas, Brazil. Lithos, 66(1-2), 37-61. https://doi.org/10.1016/ S0024-4937(02)00201-3

McDonough, W. F., Sun, S.-S. (1995). Composition of the Earth. Chemical Geology, 120(3-4), 223-253. https://doi. org/10.1016/0009-2541(94)00140-4

Minuzzi, O. R. R. (2005). Gênese e evolução da mineralização de criolita, pirocloro e columbita da subfácies albita granito de núcleo, mina Pitinga, Amazonas, Brasil. 182 p. Tese (Doutorado). Porto Alegre: Instituto de Geociências, PósGraduação em Geociências - UFRGS. 
Minuzzi, O. R. R., Bastos Neto, A. C., Flores, J. A. A., Pereira, V. P., Ferron, J. T. M. M. (2006). O Depósito Criolítico Maciço e o minério disseminado de criolita associado à fácies albita granito do granito Madeira na Mina Pitinga (Amazonas). Revista Brasileira de Geociências, 36(1 Supl.), 104-123.

Pires, A. C. (2010). Xenotima, gagarinita, fluocerita e waimirita da mina Pitinga (AM): mineralogia e avaliação preliminar do potencial do albita granito para exploração de elementos terras raras e itrio. Tese (Doutorado). Porto Alegre: Universidade Federal do Rio Grande do Sul.

Pires, A. C., Bastos Neto, A. C., Pereira, V. P., Botelho, N. F., Minuzzi, O. R. R. (2006) Gagarinita-(Y) com polimorfo de fluocerita: provável caso de formação de um novo mineral por exsolução de ETRL a partir de fluoreto de ETRP (Mina de Pitinga-AM). Revista Brasileira de Geociências, 36(1), 155-164.

Ronchi, L. H., Bastos Neto, A. C., Minuzzi, O. R. R., Althoff, F. J., Weber, M. L., Gedoz, S. C. (2005). Caracterização Físico-Química de fluidos mineralizantes da criolita de Pitinga - AM. In: Congresso Brasileiro de Geoquímica, 10., e Simpósio de Geoquímica dos Países do Mercosul, 2. Anais. Porto de Galinhas: SBGq.
Ronchi, L. H., Bastos Neto, A. C., Samuel, C. G. S. C., Weber, M. L., Pereira, V. P., Andrek, M. (2011). A Transição Magmático-Hidrotermal Registrada por Inclusões Fluidas no Albita-Granito de Núcleo, Mina Pitinga, Amazonas. In: J. C. Frantz; J. C. Marques; H. Jost (Eds.), Contribuições à Metalogenia do Brasil (215). Porto Alegre: Instituto de Geociências/UFRGS.

Shand, S. J. (1943). Eruptive rocks: their genesis, composition, classification, and their relation to ore deposits with a chapter on meteorite. Nova York: J. Wiley, 444 p. https:// doi.org/10.1038/120872a0

Streckeisen, A. (1967). Classification and nomenclature of igneous rocks. Final report of an inquiry. Abhandlungen: Neues Jahr buch für Mineralogie.

Weber, M. L., Gedoz, S. C., Benetti, F., Petry, A. C., Ronchi, L. H., Bastos Neto, A., Pereira, V. P., Althoff, F. J. (2007). Variações mineralógicas e petrográficas na porção central do albita-granito Madeira, Pitinga, AM. Gaea, 3(1), 9-17.

Winter, J. D. (2001). An introduction to igneous and metamorphic petrology. Upper Saddle River, Nova Jersey: Prentice Hall, 697 p. 